\title{
THE CONSENT OF THE GOVERNED: CONSTITUTIONAL AMENDMENT OUTSIDE ARTICLE V
}

\author{
Akhil Reed Amar*
}

We hold these truths to be self-evident, that all men are created equal, that they are endowed by their Creator with certain unalienable Rights. ... That ... Governments ... deriv[e] their just powers from the consent of the governed. That whenever any Form of Government becomes destructive of [its] ends, it is the right of the People to alter or abolish it, and to institute new Government, laying its foundations on such principles and organizing its Powers in such form, as to them shall seem most likely to effect their Safety and Happiness. ${ }^{1}$

Ringing words-but words that ring hollow today. Mark Twain once defined a literary "classic" as a work "whicl people praise and don't read." Jefferson's majestic proclamation of self-evident truths lias reached an even more exalted status: words which people praise and do read, but don't understand. For if understood, these words, and their evolving meaning between 1776 and 1789 , call for a fundamental rethinking of conventional understandings of the U.S. Constitution. Concretely, the U.S. Constitution is a far more majoritarian and populist document than we have generally thought; and We the People of the United States have a legal right to alter our Government-to change our Constitution-via a majoritarian and populist mechanism akin to a national referendum, even though that mechanism is not explicitly specified in Article V.

Or so I have argued elsewhere. I first presented my musings on the topic in the shadow of Jefferson's beloved Monticello, at the University of Virginia that he founded. My conclusion troubled me-1 suspected my audience might well wonder if someone had been messing with the drinking water in New Haven-so I invited my audience to show me where I had gone wrong. Many posed thoughtful questions, but none that went to the heart of the thing. When I sketched my preliminary

* Southmayd Professor, Yale Law School.

This essay derives from the Southmayd Inaugural Lecture, delivered at Yale Law School on November 30,1993. Generous research support was furnished by Columbia Law School, where I served as Samuel Rubin Visiting Professor of Law during the summer and fall of 1993.

For comments on early drafts, I am grateful to Bruce Ackerman, Vik Amar, John Harrison, Matt Herrington, Neal Katyal, Mike Klarman, Sandy Levinson, Henry Monaghan, Gerry Neuman, Vinita Parkash, Mike Paulsen, Rick Pildes, Larry Sager, Ron Wright, and the members of the Columbia Faculty Workshop and the NYU Constitutional Theory Colloquium.

This essay is dedicated to my mother.

1. The Declaration of Independence para. 2 (U.S. 1776).

2. 1 Mark Twain, Following the Equator: A Journey Around the World 241 (New York, Harper \& Row 1897). 
analysis in print-in the Fall 1988 University of Chicago Law Review-I began by acknowledging that my conclusions "may at first seem fanciful" and that I would probably need more than the "brief space" of that article to persuade the legal community "beyond all doubt." ${ }^{\text {"3 }}$ Near the end, I noted that my analysis of Article $\mathrm{V}$ "may well scare [the reader.] To be honest, it scares me a little too." 4 Once again, I welcomed and waited for refutation. In the years since then, I have read more widely on the topic and had countless conversations with students, colleagues, and critics. And today, I must say, I am more confident about my Article V conjecture than I was in 1988. Of course it remains quite possible that I have simply not done my sums straight. And so I now propose to revisit and revise the basic "proof" of my "conjecture" - with apologies to Fermat, let's call it my "First Theorem"-and to ask once again: what's wrong with this picture?

In Part I of what follows, I describe two plausible interpretations of Article V. The conventional reading of Article V sees it as the exclusive mechanism of lawful constitutional amendment, whereas a popular sovereignty reading insists that Article $\mathrm{V}$ establishes only the exclusive mechanism of lawful amendment by ordinary Govermment officials (Congress and state legislatures). To adjudicate between these two plausible interpretations, we must examine the rest of the Constitution. That examination occurs in Part II. I argne that unlike Jefferson's Declaration of 1776, the Constitution was lawful, not revolutionary. Between the Revolution and the Constitution, popular sovereignty principles in America evolved beyond the Lockean core of the Declaration and established the legal right of the polity to alter or abolish their government at any time and for any reason, by a peaceful and simple majoritarian process. Although various pre-1787 state constitutions featured clauses analogous to Article V that at first seemed to specify the exclusive mode of lawful constitutional change, these Article V analogues were not in fact exclusive; a popular majority retained a legal right to alter or abolish outside these Article $V$ analogues. I argue that Article V itself is likewise nonexclusive, and that majoritarian popular sovereignty principles are clearly a part of the U.S. Constitution in both word and deed, whether one focuses on the very act of ordainment and establishment or on the texts of the Preamble and the First, Ninth, and Tenth Amendments. In Part III, I acknowledge and try to refute important objections to this claim.

\section{What Article V Does Not Say and Cannot Do}

My proposition is that We the People of the United States-more specifically, a majority of voters-retain an unenumerated, constitutional right to alter our Government and revise our Constitution in a way not

3. Akhil Reed Amar, Philadelphia Revisited: Amending the Constitution Outside Article V, 55 U. Chi. L. Rev. 1043, 1044 (1988).

4. Id. at 1096. 
explicitly set out in Article V. Specifically, I believe that Congress would be obliged to call a convention to propose revisions if a majority of American voters so petition; and that an amendment or new Constitution could be lawfully ratified by a simple majority of the American electorate. Let us first consider the words of Article V:

The Congress, whenever two thirds of both Houses shall deem it necessary, shall propose Amendments to this Constitution, or, on the Application of the Legislatures of two thirds of the several States, shall call a Convention for proposing Amendments, which, in either Case, shall be valid to all Intents and Purposes, as Part of this Constitution, when ratified by the Legislatures of three fourths of the several States, or by Conventions in three fourths thereof, as the one or the other Mode of Ratification may be proposed by the Congress; Provided that no Amendment which may be made prior to the Year One thousand eight hundred and eight shall in any Manner affect the first and fourth Clauses in the Ninth Section of the first Article; and that no State, without its Consent, shall be deprived of its equal Suffrage in the Senate. ${ }^{5}$

Begin by noting what Article $\mathrm{V}$ does not say. It emphatically does not say that it is the only way to revise the Constitution. Of course, we often read the enumeration of one mode (or in this case four modes, if we multiply the two Article V mecbanisms for proposing amendments by the two Article $\mathrm{V}$ mechanisms for ratifying them) as impliedly precluding any other modes. Congress cannot generally exercise powers other than those enumerated in Article I, section 8; or generally pass laws other than via bicameralism and presentment; and so on. But there is an alternative way of understanding the implied exclusivity of Article V: it enumerates the only mode(s) by which ordinary Government-Congress and state legislatures-can change the Constitution, and thereby free themselves from various limits on their power imposed by the Constitution itself. (Without Article V, Government would have no such power.) ${ }^{6}$ Under this alternative view, Article V nowhere prevents the People themselves, acting apart from ordinary Government, from exercising their legal right to alter or abolish Government via the proper legal procedures. Article V presupposes this background legal right of the people, and does nothing to interfere with it. It merely specifies how ordinary Government can amend the Constitution without recurring to the People themselves, the true and sovereign source of all lawful power.

This alternative reading taps into Jefferson's self-evident truths. ${ }^{7}$ Jefferson sharply distinguishes between Government and the People, and so does this alternative reading. Jefferson explicitly speaks of the right of

5. U.S. Const. art. V.

6. See Gordon S. Wood, The Creation of the American Republic, 1776-1787, at 273, 276, 277, 290, 306, 337 (1969).

7. It also in some respects goes beyond the core meaning of Jefferson's words as understood in 1776. See infra text accompanying notes 17-19, 62-65. 
"the People" to re-Constitute their Government and so do various provisions of the U.S. Constitution-the Preamble and the First, Ninth, and Tenth Amendments-that support the alternative reading of Article V. (We shall return to these provisions later.)

The conventional view of Article V sees it as implementing Jefferson's formulation rather than supplementing it. But this makes hash of Jefferson's language and logic. First, Article $V$ is Government-driven: if exclusive, it gives ordinary Government officials-Congress and state legislatures-a monopoly on initiating the process of constitutional change. By contrast, Jefferson's self-evident truth, and the popular sovereignty ideology that emerged from the American Revolution, are People-driven. Popular sovereignty cannot be satisfied by a Government monopoly on amendment, for the Government might simply block any constitutional change that limits Government's power, even if strongly desired by the People. (Elections for Government officials do not solve this problem; in the 1780s, not all members of the polity were even eligible to vote for, say, state senators-who in turn helped elect U.S. Senators; but all members of the polity-"freemen," in 1787-were by definition part of "the People" eligible to participate in People-driven constitutional change.) $)^{8}$ Second, and related, Article $V$ is minoritarian. Precisely because ordinary Government is distrusted, it may not amend the Constitution without amassing an extraordinary bloc of Government officials. ${ }^{9}$ A mere minority of officials may often stymie constitutional change. But, as we shall see below, Jefferson's self-evident truth and the spirit of popular sovereignty it unleashed were universally understood in 1787 as majoritarian. A simple majority of the People themselves-members of the polity-had a legal right to alter Government and change Constitutions. If exclusive, Article $V$ betrays this right, for it is child's play to conjure up cases where the obstacle course of Article $V$ would block the amendment path, even if a bona fide majority of American voters enthusiastically supported amendment.

It appears, then, that there are two plausible interpretations of the implied exclusivity of Article V: (1) the conventional reading that it enu-

8. For discussions of the special franchise rules in effect when "the People" ratified constitutions, see Samuel B. Harding, Party Struggles Over the First Pennsylvania Constitution, Annual Report of the American Historical Association for the Year 1894, at 371, 371-75 (1895); Wood, supra note 6, at 289; James G. Pope, Republican Moments: The Role of Direct Popular Power in the American Constitutional Order, 139 U. Pa. L. Rev. 287, 338 \& n.235 (1990). For a similar analysis of Reconstruction era conventions, see Michael Les Benedict, A Compromise of Principle 108 (1974). To take a more modern example: even if today's electorate strongly desires legislative term limits, ordinary legislators may simply block any constitutional amendment to that effect. And the electoral check against this kind of self-dealing is quite weak; any district whose voters punish the incumbent by throwing the rascal out will lose legislative seniority and clout visá-vis other districts, in a kind of prisoners' dilemma. See Akhil Reed Amar \& Vik Amar, President Quayle?, 78 Va. L. Rev. 913, 928-29 (1992).

9. See 2 The Works of James Wilson 509 (Robert G. McCloskey ed., 1967); Amar, supra note 3, at 1093-94 \& n.180. 
merates the only mode(s) by which the Constitution may be amended, and (2) an alternative reading that it enumerates the only mode(s) by which ordinary Government may amend the Constitution. How shall we decide which is the better reading? By widening our focus beyond the narrow text of Article $\mathrm{V}$ to consider other parts of the original Constitution, various glossing provisions of the federal Bill of Rights, and various Article $\mathrm{V}$ analogues in state constitutions.

Widening our frame will also help cure an underlying anxiety that, I think, may wrongly tilt lawyers towards the conventional reading of Article V exclusivity. The Constitution is supreme law, and the legal rules it establishes for its own amendment are of unsurpassed importance, for these rules define the conditions under which all other constitutional norms may be legally displaced. It is comforting to believe that Article V lays down these all-important legal rules with precision. If we stick close to Article V, we are safe: if we go beyond it, we are at sea.

But this picture is an optical illusion. Article $V$ is far less precise than we might expect. What voting rule must an Article $V$ proposing convention follow? What apportionment ratio? Can an amendment modify the rules of amendment themselves? If so, couldn't the "equal suffrage" rules of Article $\mathrm{V}$ be easily evaded by two successive "ordinary" amendments, the first of which repealed the equal suffrage rules themselves, and the second of which reapportioned the Senate? Could a legitimate amendment generally purport to make itself (or any other random provision of the Constitution) immune from further amendment? If so, wouldn't that clearly violate the legal right of future generations to alter their Government? Wouldn't the same be true of an amendment that effectively entrenched itself from further revision by, say, outlawing criticism of existing law? But if that would be unconstitutional, haven't we in effect made the narrow and hard core of our First Amendment itself unamendable?

If determinate answers to these and other questions exist, they lie outside Article V, narrowly construed-in other provisions of the Constitution, in the overall structure and popular sovereignty spirit of the document, in the history of its creation and amendment, and in the history of the creation and amendment of analogous legal documents, such as state constitutions. And once we consult these sources, we will find that we are in fact not at sea. ${ }^{10}$ The very sources that render Article V rules determinate also clarify the equally determinate rules for Peopledriven, majoritarian constitutional change outside Article V. By 1787, at least, the legal rules underlying Jefferson's right of the People to alter or abolish were no murkier or more mysterious than those encoded in Article V.

10. For a brief discussion of how these intra-Article $\mathrm{V}$ questions should be resolved in light of the theory and evidence presented here, see infra note 154. 


\section{What the Rest of the Constitution Does SAY and Do}

In considering the "Constitution" as a whole, we must remember that it is not simply a text, but an act: the found-ing and constitut-ing-in the Preamble's phrase, the "ordain [ing]" and "establish[ing]" —of a new nation and a new regime of governance. And more: this act of founding, of constitution, was-and was universally understood to be in 1787-itself an act of "the People" exercising and implementing their "self-evident" right to "alter or abolish" existing Government "and to institute new Government, laying its foundations on such principles and organizing its Powers in such form, as to them shall seem most likely to effect their Safety and Happiness." If you have any doubts, just listen to the Preamble with fresh ears, and hear how it self-consciously echoes and paraphrases Jefferson's self-evident Declaration:

We the People of the United States, in Order to form a more perfect Union, establish Justice, insure domestic Tranquility, provide for the common defense, promote the general Welfare, and secure the Blessings of Liberty to ourselves and our Posterity [i.e., in order to "effect" our "Safety and Happiness"], do ordain and establish [i.e., "institute"] this ["new"] Constitution for the United States of America. ${ }^{11}$

We shall ponder this text more carefully later. But for now, let's focus on the act of constitution itself. What does the act say and do-for it does by saying and says by doing-about the legal right of We the People to alter or abolish what We have legally ordained and established?

\section{A. The Legality of the Constitution}

One camp of modern scholars might quickly answer, "nothing at all." Some scholars claim that the Constitution of 1787 was itself illegal.12 If indeed the Constitution "was itself the product of blatant and conscious illegality,"13 perhaps it tells us nothing about the People's legal right to

11. U.S. Const. pmbl. (emphasis added).

12. See, e.g., Bruce A. Ackerman, The Storrs Lectures: Discovering the Constitution, 93 Yale L.J. 1013, 1058 (1984) (declaring that ratification of Constitution was, under preexisting law, "plainly illegal"); Richard S. Kay, The Illegality of the Constitution, 4 Const. Commentaries 57, 70 (1987) ("[T]he entire ratification process was undertaken without legal sanction and, in significant part, in contradiction to law.").

13. Kay, supra note 12, at 57. In his recent book, Professor Ackerman writes that he finds "Profesor [sic] Kay's arguments establishing the illegality of the Constitution more persuasive than Professor Amar's [attempted refutation.]" Bruce Ackerman, We the People 328 n.4 (1991). This statement is puzzling given that Professor Kay nowhere even shows his awareness of-much less refutes-the Federalists' compelling rejoinder to the claim of illegality made by the Constitution's opponents. See infra text accompanying notes 20-36 (discussing "breached treaty" rejoinder).

It is also odd that both Ackerman and Kay ignore the strongest and most interesting claim of illegality, which focuses not on the Articles of Confederation, but on the preexisting state constitutions. See infra text accompanying notes 37-39. 
alter or abolish. ${ }^{14}$ Under this "illegal" argument, the Constitution was a second American revolution, different only from the first and its 1776 Declaration in that the second was bloodless.

1. Legality and the Declaration. - While I applaud any effort to place the Constitution and Declaration side by side, this "illegal" argument misses important differences between the two documents-and indeed between the meaning of Jefferson's words in 1776 and their meaning in 1787. When written in 1776, Jefferson's words in large part appealed to a Lockean right of violent revolution, triggered when Government had breached its pact with the citizenry by violating fundamental rights. ${ }^{15}$ This Lockean right required no vote of the People themselves. And if a legal vote were to be taken in 1776, it was far from clear that the voters should include only Englishmen in America but not Englishmen in Britain, since it was doubtful that prior to $\mathbf{1 7 7 6}$ Americans and Britons were in law distinct sovereign peoples. (Jefferson thought they were distinct and said so in early drafts of the Declaration, but the Continental Congress edited these passages out. ${ }^{16}$ If Americans were indeed distinct from the time of their crossing the ocean, by what right had Parliament ever legislated for them?) Precisely because the right of revolution required force-bullets, not ballots-it could be invoked only if a convincing case could be made of Government oppression. Thus the main purpose of the Declaration was to make this Lockean/revolutionary case by submitting "Facts . . . to a candid world," piling up example upon example of one act of oppression after another, amounting to "a long train of abuses and usurpations" evincing a "design to reduce [Americans] under absolute Despotism."17

But once the Revolution succeeded, Americans re-Constituted their colonial governments on purely democratic rather than monarchical foundations. As we shall soon see, over the next decade the previously revolutionary right to alter and abolish became domesticated and legalized in each of the thirteen former colonies. Ballots would replace bullets, and the People could exercise this right not simply (as Jefferson's initial phrase could be read to imply) "whenever any Form of Government becomes destructive of [its] ends" by violating unalienable rights, but at any time and for any reason that the People (by majority vote) deemed suffi-

14. Professor Ackerman, who insists that the Constitution was "plainly illegal" yet furnishes a sturdy precedent for future legal amendments, openly flirts with paradox, if not contradiction. If James Madison's and James Wilson's Constitution violated pre-existing legal rules, how was it any different from Jefferson Davis's Confederate Constitution, except that Madison and Wilson succeeded, ex post, and Davis did not? Ackerman's "laws" of amendment seem more laws of political science-empirical regularities, like the "laws" of supply and demand-than formal, legal, procedural laws that specify an ex ante rule of recognition.

15. See John Locke, The Second Treatise of Government $\S \S 221,243$ (C.B. Macpherson ed., 1980).

16. See Gary Wills, Inventing America 76-90 (1978).

17. The Declaration of Independence para. 2 (U.S. 1776). 
cient. By 1787, the accent had shifted to Jefferson's more expansive clause stressing the People's power to institute new Governments as "to them"-not anyone else, not a king, not the world-"shall seem most likely to effect their Safety and Happiness." ${ }^{18}$

This evolution and legalization was a truly transcendent American achievement, played out on the high political stage of each of the thirteen states in the thirteen fateful years between 1776 and 1789. For as we shall soon see in greater detail, individual states echoed the Declaration of 1776 and extended it, giving the people's right to alter or abolish a precise, regular, peaceful, and legal form that it lacked before 1776. Sovereignty was not merely derived from the People-to be momentarily reclaimed by them only in awful spasms of revolutionary violence-but inalienably vested in and retained by the People, and could be exercised peacefully by simple majorities at the polls and in special popular assemblies/conventions. By 1787, the transition was complete. The Constitution needed no long train of abuses by state governments to justify itself, and recited none. In contrast to the Declaration, it submitted itself to a peaceful popular vote in each state, under principles of majority rule. Unlike American Loyalists in 1776 who took up arms against the Declaration, the loyal opposition to the Constitution in 1787 fought the good fight in conventions and not on battlefields. And when outvoted-often by simple majorities-Anti-Federalists in every single state ultimately accepted the outcome because deep down, they too understood the Federalists' claim that the Constitution had been legally ratified. ${ }^{19}$

But not before trying to brand the proposed Constitution "illegal" early in the game. The "illegal" gambit took two forms. Both gambits were plausible, but in the end both gambits properly failed.

2. Legality and the Confederation. - The first gambit focused on the inconsistency between Article VII of the proposed Constitution and Article XIII of the Articles of Confederation. ${ }^{20}$ Begin with Article VII, the last section of the Constitution, that explains its first, the Preamble. The Preamble says that "We the People do ordain and establish this Constitution" and Article VII says how we do this:

18. For clear, self-conscious discussions of this shift, see 2 Jonathan Elliot, The Debates in the Several State Conventions on the Adoption of the Federal Constitution 432-33 (J.B. Lippincott \& Co. 1881) (1836) [hereinafter Elliot's Debates] (remarks of James Wilson in Pennsylvania ratifying debates); 4 id. at 229-30 (remarks of James 1redell in North Carolina ratifying convention); 1 The Works of James Wilson, supra note 9, at 77-79; Wood, supra note 6, at 343 (quoting Thomas Tudor Tucker of South Carolina). These sources are analyzed infra text accompanying notes 58-65.

19. The "illegal" argument cannot account for any of this.

20. I begin with this gambit because it is the best known among citizens and scholars and the exclusive subject of most legal analysis of the Constitution's legality. What's more, the ultimate failure of this gambit will lead us directly to the Anti-Federalists' second and more important gambit focusing on state law and state constitutions. See infra text accompanying notes $37-61$. 
The Ratification of the Conventions of nine States shall be sufficient for the Establishment of this Constitution between the States so ratifying the Same. ${ }^{21}$

Now contrast Article XIII of the Articles of Confederation:

And the Articles of this confederation shall be inviolably observed by every state, and the Union shall be perpetual; nor shall any alteration at any time hereafter be made in any of them; unless such alteration be agreed to in a congress of the United States, and be afterwards confirmed by the legislatures of every state. ${ }^{22}$

These provisions are undeniably inconsistent. The Constitution speaks of nine states; the Articles, of all thirteen. The Constitution relies on state conventions, yet the Articles require approval by state legislatures. And make no mistake, Article XIII purports to be exclusive. Unlike the pointed omission of the word "only" in the Constitution's Article V, Article XIII clearly regulates "any alteration" of the Articles. The Constitution, of course, was a proposed alteration.

But inconsistency is not illegality. The Articles of Confederation were nothing more than a tight treaty among thirteen otherwise independent states-a self-described "firm league of friendship" in which each state expressly "retains its sovereignty." ${ }^{33}$ Like the later Congress of Vienna, its "Congress" was merely an international assembly of ambassadors, sent, recallable, and paid by state governments with each state casting a single vote as a state. It nowhere described itself as a "Government" or "legislature," or its pronouncements as "law." By 1787, the Articles had been routinely and flagrantly violated on all sides. ${ }^{24}$ And under well-established legal principles in 1787, these material breaches freed each compacting party-each state-to disregard the pact, if it so chose. Thus, Blackstone wrote in his best-selling Commentaries that in a "foederate alliance" - that is, a confederation, or league of otherwise sovereign statesan infringement of fundamental conditions "would certainly rescind the compact." 25

Nor does Article XIII's declaration that "the Union shall be perpetual" change the analysis, for in fact this clause was itself yoked to a mandate that the Articles "shall be inviolably observed by every state." Under standard principles of international law, each of these yoked mandates was a condition of the other. When inviolable observation lapsed, so did perpetual union under the Articles. (Indeed, international law principles help explain why perpetuity and inviolability were pointedly paired.) To put the matter another way, the key point about the Confederation was

21. U.S. Const. art. VII (emphasis added). I add this emphasis to highlight the connection between the Preamble and Article VIl.

22. Articles of Confederation art. XIII.

23. Id. arts. II-III.

24. See, e.g., James Madison, Vices of the Political System, in The Mind of the Founder 57-59 (Marvin Meyers ed., 1981) [hereinafter Vices].

25. 1 William Blackstone, Commentaries 98 note e (added in 1766 edition). 
that it was a league, a treaty. The word "perpetual" said what kind of league it would be: the strongest, the firmest of leagues-as leagues gobut a league nonetheless. And the rule Blackstone invoked applied to all leagues, weak or strong, firm or mushy. In the words of the Swiss jurist Emmerich de Vattel, whose Law of Nations was widely read and cited in America, "several sovereign and independent states may unite themselves together by a perpetual confederacy without each in particular ceasing to be a perfect state." 26

Here then, is a powerful rejoinder to the first "illegal" gambit: the Constitution did not "illegally" depart from Article XIII because that Article and the other Articles of Confederation were by 1787 no longer legally binding for any state that chose to exercise its legal right to rescind the compact. This powerful rejoinder is no mere twentieth century fabrication. On the contrary, when pressed, leading law-trained friends of the Constitution repeatedly resorted to this rejoinder in 1787-1788.

Having clearly set out the breached treaty argument in the months before the Philadelphia Convention in his now-famous Vices of the Political System, ${ }^{27}$ James Madison wielded the argument as a cudgel in Philadelphia, early and often-tentatively at first, but with increasing firmness as the weeks passed. Here is Madison on June 5:

[A]s far as the articles of Union were to be considered as a Treaty only of a particular sort, among the Governments of Independent States, the doctrine might be set up that a breach of any one article, by any of the parties, absolved the other parties from the whole obligation. ${ }^{28}$

And two weeks later:

Clearly, according to the Expositors of the law of Nations, ... a breach of any one article, by any one party, leaves all the other parties at liberty, to consider the whole [compact] as dissolved. ... [T] he violátions of the federal articles had been numerous \& notorious. . . . He did not wish to draw any rigid inferences from these observations. ${ }^{29}$

On June 30, and more tartly:

26. Emmerich de Vattel, The Law of Nations bk. 1 ch. $1 \S 10$ (London, J. Coote 1760). The leading modern historian of the era, Gordon S. Wood, agrees with my assessment of the Articles here. See Wood, supra note 6, at 355.

27. See Vices, supra note 24 , at 61 . General Jedediah Huntington likewise appealed to the breached treaty argument in May 1787, urging the Connecticut legislature to send a delegation to Philadelphia: "[T]he compact between the several states has not any penalty annexed to it for the breach of its conditions.... [W] henever therefore any state refuses a compliance with a requisition made agreeably to the confederation, all obligation on the part of the other states is dissolved." Connecticut Courant, May 21, 1787, at 2, reprinted in 13 The Documentary History of the Ratification of the Constitution 106 John P. Kaminski et al. eds., 1981).

28. 1 The Records of the Federal Convention of 1787, at 122-23 (Max Farrand ed., 1937) [heremafter Farrand] (angle brackets deleted).

29. Id. at 315 . 
In reply to the appeal of Mr. E. to the faith plighted in the existing federal compact, he remarked that the party claiming from others an adherence to a common engagement ought at least to be guiltless itself of a violation. ${ }^{\mathbf{3 0}}$

And later still, on July 23, when Madison may well have had his copy of Blackstone in hand as he sharply distinguished, as had Blackstone, "between a league or treaty, and a Constitution":

The doctrine laid down by the law of Nations, in the case of treaties is that a breach of any one article by any of the parties, frees the other parties from their engagements. In the case of a union of people under one Constitution, the nature of the pact has always been understood to exclude such an interpretation. ${ }^{31}$

Six months later, as a member of the pseudonymous trio Publius, Madison penned the Federalist Number 43 for public consumption:

[A question] of a very delicate nature present [s itself] on this occasion: ... On what principle the Confederation, which stands in the solemn form of a compact among the States, can be superseded without the unanimous consent of the parties to it?

... Perhaps also, an answer may be found without searching beyond the principles of the compact itself. ... A compact between independent sovereigns, founded on ordinary acts of legislative authority, can pretend no higher validity than a league or treaty between the parties. It is an established doctrine on the subject of treaties that all the articles are mutually conditions of each other; that a breach of any one article is a breach of the whole treaty; and that a breach, committed by either of the parties, absolves the others, and authorizes them, if they please, to pronounce the compact violated and void. Should it unhappily be necessary to appeal to these delicate truths for a justification for dispensing with the consent of particular States to a dissolution of the federal pact, will not the complaining parties find it a difficult task to answer the multiplied and important infractions with which they may be confronted? The time has been when it was incumbent on us all to veil the ideas which this paragraph exhibits. ${ }^{32}$

The Federalist Papers, of course, enjoyed widespread currency, but other leading Federalists also developed the breached treaty rejoinder. A week before the publication of the Federalist Number 43 in New York, Charleston's Charles Cotesworth Pinckney-who in his youth had studied law at Oxford under Sir William Blackstone himself-lectured the South Carolina Convention as follows:

The honorable gentleman says, compacts should be binding, and that the Confederation was a compact. It was so; but it was a compact that had been repeatedly broken by every state in the

30. Id. at 485 . "Mr. E" here is Oliver Ellsworth.

3I. 2 id. at 93.

32. The Federalist No. 43, at 279-80 (Clinton Rossiter ed., 1961). 
Union; and all the writers on the laws of nations agree that, when the parties to a treaty violate it, it is no longer binding. ${ }^{33}$ Pinckney's neighbor to the north, James Iredell-who would soon serve as Associate Justice of the U.S. Supreme Court-hammered home the same theme:

Perhaps every state has committed repeated violations of the demands of Congress. ... The consequence is that, upon the principle I have mentioned, (and in which I believe all writers agree,) the Articles of Confederation are no longer binding. ${ }^{34}$

Though the Federalists developed the breached treaty rejoinder with skill and precision, they did not shout it from the rooftops. And, in Madison's voice at least, we hear a distinct note of restraint. He began at Philadelphia by noting that the doctrine "might be" set up, and that he did not "wish to draw any rigid inferences." The question was "very delicate," in the words of Number 43, where he prefaced his exposition with a pointedly italicized "perhaps" and admitted that he raised the breached treaty defense "unhappily." But this restraint had nothing to do with law and everything to do with politics. A breached treaty was voidable, not void ab initio. A state might have a right to withdraw, but was withdrawal a wise move-especially if the Constitution failed to be ratified? Perhaps even a flawed and breached alliance was better than none, and Madison was not the kind of man to fling off his only garments, however tattered, before his new suit arrived. What's more, to establish conclusively the requisite breaches in fact would have required lots of awkward and nasty fingerpointing-hardly the kind of thing conducive to the launching of a new nation in the spirit of harmony and good will. Hence Madison's unhappiness and lack of rigidity, and his cryptic line, "The time has been when it was incumbent on us all to veil the ideas which this paragraph exhibits."

But politics aside, the Federalists' rejoinder was an apparent winner, legally speaking. Over and over Madison referred to established legal "doctrine"; the legal issue, he said, was "clear[ ] according to the Expositors of the law of Nations." The breached treaty rejoinder was a "delicate truth []." Pinckney appealed to "all the writers on the laws of nations" and Iredell declared that "all writers agree." These men knew what they were talking about. And not a single Anti-Federalist, to my knowledge, contradicted them on this key point. ${ }^{35}$ When the issue was joined, the Anti-

33. 4 Elliot's Debates, supra note 18 , at 308 .

34. Id. at 230. The breached treaty rejoinder also appeared in private correspondence. See, e.g., Letter from John Brown Cutting to William Short, in 14 Documentary Fistory of the Ratification of the Constitution 492, 497 (Jan. 9, 1788) (John P. Kaminski \& Gaspare J. Saladino eds., 1983); Letter from Samuel Holden Parsons to William Cushing (Jan. 11, 1788), in 1 The Debate on the Constitution 743, 748 (Bernard Bailyn ed., 1993).

35. Alexander Hamilton had expressed some early reservations about the breached treaty argument at Philadelphia. See 1 Farrand, supra note 28, at 324-25. But these had apparently lapsed by the time of his Publian collaboration with Madison, as had his early 
Federalists caved; when pressed to put up or shut up, they shut up. ${ }^{36}$ Their first "illegal" gambit failed, and rightly so.

3. Legality and State Constitutions. - But the very failure of the first "illegal" gambit leads to the second, far more interesting one. If indeed, the Articles of Confederation were a mere treaty among otherwise independent nations, ${ }^{37}$ we must carefully consider the laws of these nations-the thirteen states-and their relation to the Constitution. Undeniably, the U.S. Constitution, when adopted, would effect important changes in the internal governance of each state-for example by stripping the state legislature of the power to emit bills of credit, or impair the obligation of contracts, even if the pre- 1787 state constitution authorized these actions. ${ }^{38}$ The key question thus became, by what legal right would Article VII ratification of the Constitution in, say, the Maryland Convention alter the existing Maryland Constitution? The Maryland Constitu-

reservations about the theory of extended republics Madison floated in Philadelphia and featured in The Federalist Number 10. See id. at 147. But perhaps Hamilton-who supervised publication of The Federalist Papers in New York-was responsible for the italicized perhaps in Number 43.

Oliver Ellsworth also resisted Madison's breached treaty argument at Philadelphia, labelling it "highly dangerous," id. at 335. And "dangerous" it was, as Madison was the first to admit. But "dangerous" is not "incorrect," and Ellsworth failed to identify any legal flaw in the argument.

36. As states' rightists, most Anti-Federalists were hardly in a position to rebut the states' rights gloss placed on the Articles of Confederation by the breached treaty rejoinder and by the Constitution's own Article VII, see infra note 37.

37. The legally independent status of the states prior to adoption of the Constitution is supported by all the major legal documents of the era, and by broad historical evidence. For 150 years prior to independence, the individual colonies had of course been separate, having been founded at different times and with different, unique charters and forms of government. The Declaration of Independence proclaimed itself in the name of "free and independent states" -independent even of each other, save as they chose to concert their action. Given the predominance of Montesquieu's vision that a single republic could not extend over a vast geographic, cultural, and climatic range, it is somewhat fanciful to think that, legally, a continental nation was formed in 1776 with virtually no discussion, and with the patriots' continental assembly pointedly calling itself a "congress." The words of individual state constitutions, and the centrality accorded these documents by revolutionary Americans, further attest to the independence and sovereignty of states prior to 1788; and the "sovereignty" of states was, of course, the explicit hallmark of the Articles of Confederation. So too, the Treaty of Peace with Britain recognized the legal independence of individual states. Finally-and revealingly-so did Article VII of the Constitution itself, which made clear that prior to joining the Constitution's "more perfect union" each state spoke for itself and only itself, and was legally free to go its own way. Further supporting documentation and analysis appears in Akhil Reed Amar, Of Sovereignty and Federalism, 96 Yale L.J. 1425, 1444-62 (1987); and in the definitive historical account of this period, see Wood, supra note 6, at 354-59.

38. See Letter from James Madison to George Washington (April 16, 1787), in 9 The Papers of James Madison 385 (Robert A. Rutland ed., 1975); 1 Farrand, supra note 28, at 317 (remarks of James Madison); 2 id. 88 (remarks of George Mason); 2 id. 92-93 (remarks of James Madison); 3 id. 229 ("Genuine Information" of Luther Martin before Maryland legislature); The Federalist No. 44, at 286 (James Madison) (Clinton Rossiter ed., 1961). 
tion of 1776 had its own explicit amendment clause, and it, too, looked rather different from the federal Constitution's Article VII:

That this Form of Government, and the Declaration of Rights, and no part thereof, shall be altered, changed, or abolished, unless a bill so to alter, change or abolish the same shall pass the General Assembly, and be published at least three months before a new election, and shall be confirmed by the General Assembly, after a new election of Delegates, in the first session after such new election. ${ }^{39}$

Note the obvious differences between this Maryland Constitution clause and the U.S. Constitution's Article VII. The Maryland clause requires two votes; Article VII, one. The Maryland clause looks to the ordinary Government; Article VII envisions a special convention of the People of Maryland.

Here, then, was the Anti-Federalists' second "illegal" gambit: (1) the Maryland Constitution clause specified the exclusive mode by which the Maryland Constitution could be lawfully altered or abolished; (2) ratification of the federal Constitution in Maryland would indeed alter important aspects of the state constitution; but (3) the Article VII ratification mechanism did not satisfy the Maryland exclusive clause. Thus, ratification via Article VII would be illegal under pre-existing and binding Maryland law.

But once agam, the Federalists had a compelling rejoinder. And this rejoinder has enormous implications for my "First Theorem." As we shall see, the Federalists argued that the Maryland Constitution clause was best read as nonexclusive-and the logic underlying this rejoinder strongly implies that Article V of the federal Constitution is likewise best read as nonexclusive.

a. Popular Sovereignty. - In the Philadelphia Convention, Maryland's Daniel Carroll "mentioned the mode of altering the Constitution of Maryland pointed out therein, and that no other mode could be pursued in that State." 40 But listen carefully to Madison's bold yet lawyerly reply:

The difficulty in Maryland was no greater than in other States, where no mode of change was pointed out by the Constitution.... The people were in fact, the fountain of all power, and by resorting to them, all difficulties were got over. They could alter constitutions as they pleased. It was a principle in the Bills of rights, that first principles might be resorted to. ${ }^{41}$

Whereas Carroll read the Maryland amendment clause as the exclusive mode of lawful constitutional change-"no other mode could be pursued"-Madison read it more narrowly; it specified only the way ordinary Government could amend the Constitution (by two ordinary votes of two ordinary legislatures) but did not exclude the People themselves-"the

39. Md. Const. of 1776 , art. LIX.

40. 2 Farrand, supra note 28 , at 475 .

41. Id. at 476. 
fountain of all power"-from altering or abolishing their Government "as they pleased." Especially revealing is Madison's analogy to those sister states of Maryland-such as Madison's own Virginia- "where no mode of change was pointed out by the [state] Constitution." Surely, Madison suggested, that did not mean that the Constitution could never be changed. It meant only that the People themselves-and not ordinary Government-could amend. And so the addition of the Maryland clause gave ordinary Government an amending power it would not otherwise have had, but it was not best understood as depriving the People of their preexisting background right to alter or abolish at will. For that pre-existing legal right, proclaimed Madison, was one of the "first principles" of the legal order.

Madison was not alone in relying on this compelling popular sovereignty rejoinder at the Philadelphia Convention. Weeks before Madison's pointed response to Carroll, we find his Virginia colleague George Mason-author of the famous Virginia Bill of Rights of 1776, and soon to become a leading Anti-Federalist opponent of ratification-commenting on an early version of Article VII:

[T] he authority of the people [is] one of the most important and essential of the Resolutions. The Legislatures have no power to ratify [the proposed federal constitution]. They are the mere creatures of the State Constitutions, and cannot be greater than their creators. ... Whither then must we resort? To the people with whom all power remains that has not been given up in the Constitution derived from them. It was of great moment . . . that this doctrine should be cherished as the basis of free Government. ${ }^{42}$

Further support for Madison's "first principle" came even earlier at Philadelphia from the unlikely person of Alexander Hamilton, widely viewed today as no friend of popular government: "[I]f the Legislatures have no powers to ratify because thereby they diminish their own Sovereignty the people may come in on revolution Principles." 43 Or as Madison recorded the same speech in his notes: "[M] ay not the States themselves in which no constitutional authority equal to this purpose exists in the Legislatures, have had in view a reference to the people at large." 44 Indeed, Madison's "first principle" was embedded in the Virginia Resolutions introduced at the very outset of the Philadelphia conclave, which explicitly provided that whatever plan emerged from Philadelphia be submitted "to an assembly or assemblies ... to be expressly chosen by the people, to consider \& decide thereon." 45

42. Id. at 88 .

43. 1 id. at 301 . On the possible ambiguity of the phrase "revolution principles," see Amar, supra note 3, at 1050 n.19. See also 1 The Works of James Wilson, supra note 9, at 79 (using phrase "revolution principle" to refer to legal right of popular sovereiguty).

44. 1 Farrand, supra note 28, at 283.

45. Id. at 22 (emphasis added). 
During the ratification period, the Carroll-Madison exchange was in effect reenacted in several states-this time in the public spotlight. Pointing to state constitutions, various leading Anti-Federalists played the "state illegality" card. As had Carroll in Philadelphia, Luther Martin of Maryland read his state constitution's amendment clause as exclusive, as emphasized by his own italics:

As our constitution had pointed out a mode by which, and by which only, alterations, were to be made therein, a convention of the people could not be called to agree to and ratify the said form of government, without a direct violation of our constitution ....46

In Massachusetts, the state constitution contained a clause calling for a canvassing of voter sentiment in 1795; if "two-thirds of the qualified voters ... who shall assemble and vote . . . are in favor of [a constitutional] revision," the legislature would be obliged to convene a constitutional convention. ${ }^{47}$ According to a Massachusetts Anti-Federalist pamphlet, the date 1795 was not exclusive, but the rest of its rules were:

Should it be a question, whether an alteration in the Constitution can be made before the year 1795, there is nothing in the clause recited, that I can conceive to prevent it: because although in the year 1795, precepts must issue for the purposes mentioned, there is no provision to prevent their issuing, if necessary, before that period. But surely, if any alteration should be made in the Constitution, it must be in a mode provided by the Constitution itself, for otherwise the clause recited must become a nullity. ${ }^{48}$

Likewise, the Pennsylvania Constitution of 1776 contained a clause providing that in 1783 and "in every seventh year thereafter" a "council of censors" was to meet, with the power to call a convention for amending the constitution if "two-thirds of the whole number [of censors] shall agree." ${ }^{49}$ Dissenting from the Pennsylvania Convention's ratification of the U.S. Constitution, leading Pennsylvania Anti-Federalists claimed that the Pennsylvania clause was indeed exclusive, and that ratification was thus illegal under Pennsylvania law:

[The Pennsylvania Constitution] cannot legally be altered but by a recommendation of a council of censors, who alone are authorized to propose alterations and amendments. ${ }^{50}$

46. 3 id. at 229 .

47. Mass. Const. of 1780 , ch. VI, art. X.

48. A Republican Federalist (III), in 4 The Complete Anti-Federalist 169, 172 (Herbert J. Storing ed., 1981) [hereinafter Storing] (emphasis in original). Professor Storing identifies the likely author as James Warren, Speaker of the Massachusetts House of Representatives and husband of Mercy Otis Warren.

49. Pa. Const. of 1776, $\S 47$.

50. The Address and Reasons of Dissent of the Minority of the Convention of Pennsylvania To Their Constituents (Dec. 18, 1787), in 3 Storing, supra note 48, at 145, 149. 
As had Madison at Philadelphia, the Federalists responded vigorously to this Anti-Federalist gambit, playing their popular sovereignty trump card with flourish. In his first discussion of the Constitution's Article VII, Publius trumpeted popular sovereignty with capital letters: "The fabric of American empire ought to rest on the solid basis of THE CONSENT OF THE PEOPLE. . . . that pure, original fountain of all legitimate authority." ${ }_{1}$ Though echoing Madison in Philadelphia with its description of the people as the "fountain" of all lawful power, Number 22 was in fact authored by Alexander Hamilton.

But Number 22 appeared before Luther Martin and the Pennsylvanians had published their accusations of illegality; and so Publius returned to the gambit in later, more pointed, essays. In Number 39 , Madison reminded his readers that the "Constitution is to be founded on the assent and ratification of the people of America ... [and] derived from the supreme authority in each State-the authority of the people themselves." 52 In the next number, and more pointedly, Madison wrote:

[I]n all great changes of established governments forms ought to give way to substance; . . . a rigid adherence in such cases to the former would render nominal and nugatory the transcendent and precious right of the people to "abolish or alter their governments as to them shall seem most likely to effect their safety and happiness,"* .... [The proposed Constitution is] to be submitted to the people themselves, the disapprobation of this supreme authority would destroy it forever; its approbation blot out antecedent errors and irregularities.

*Declaration of Independence. ${ }^{53}$

Hamilton returned to this theme in his own Federalist Number 78, where he, too, appealed to the Declaration of Independence's self-evident populist truth:

I trust the friends of the proposed Constitution will never concur with its enemies* in questioning that fundamental principle of republican government which admits the right of the people to alter or abolish the established Constitution whenever they find it inconsistent with their happiness . . . .54

Lest his audience miss the point that he was directly rebutting the "illegal" gambit, Hamilton dropped a blunt footnote: "*Vide Protest of the Minority of the Convention of Pennsylvania, Martin's speech, etc."55

As with his development of the breached treaty rejoinder to the AntiFederalists' first "illegal" gambit, Publius did not stand alone in developing the popular sovereignty rejoinder. Most important were the arguments of James Wilson during the Pennsylvania ratifying convention.

51. The Federalist No. 22, at 152 (Alexander Hamilton) (Clinton Rossiter ed., 1961).

52. Id. No. 39, at 243 (James Madison).

53. Id. No. 40, at 252-53 (James Madison) (footnote in original).

54. Id. No. 78, at 469 (Alexander Hamilton).

55. Id. 
Though less famous today than some of his companions, Wilson deserves our most careful attention. He was one of only six men to sign both the Declaration of Independence and the Constitution. At Philadelphia, he played a role second-if that-only to Madison. As Gordon Wood bas written, Wilson was the Federalists' preeminent popular sovereignty theorist; ${ }^{56}$ and it was his hand that first penned the bold first three words of the Constitution, "We the People." 57 In the 1780s, Wilson was universally regarded as perhaps the most brilliant, scholarly, and visionary lawyer in America. Within three years of the Constitution's ratification, he would spearhead a successful effort to replace the Pennsylvania Constitution of 1776, serve as one of the first five Associate Justices of the U.S. Supreme Court, found the University of Pennsylvania Law School, and deliver the most important and celebrated lectures on law ever given in eighteenth century America.

Wilson dominated the Pennsylvania ratifying convention, in a one man tour de force. Early on, he laid down these first principles:

There necessarily exists, in every government, a power from which there is no appeal, and which, for that reason, may be termed supreme, absolute, and uncontrollable ....

Perhaps some politician, who has not considered with sufficient accuracy our political systems, would answer that, in our governments, the supreme power was vested in the constitutions. . . . This opinion approaches a step nearer to the truth, but does not reach it. The truth is, that, in our governments, the supreme, absolute, and uncontrollable power remains in the people. As our constitutions are superior to our legislatures, so the people are superior to our constitutions. Indeed, the superiority, in this last instance, is much greater; for the people possess over our constitutions control in act, as well as right.

The consequence is, that the people may change the constitutions whenever and however they please. This is a right of which no positive institution can ever deprive them. 58

This eye-opening last paragraph was no mere slip of the tongne, or vague theory, for Wilson's very next words reminded bis audience that the ratifying Convention itself-meeting pursuant to the proposed Constitution's Article VII-embodied these first principles. Thus, the legal word was made fiesh:

56. See Wood, supra note 6 , at 530 ("More boldly and more fully than anyone else, Wilson developed the [popular sovereignty] argnment that would eventually become the basis of all Federalist thinking.").

57. 2 Farrand, supra note 28 , at 150.

58. 2 Elliot's Debates, supra note 18, at 432 (emphasis added to last paragraph). In the McMaster and Stone edition of this speech, Wilson goes on to describe this right as "a power paramount to every constitution, inalienable in its nature." Pennsylvania and the Federal Constitution 230 (James B. McMaster \& Frederick Stone eds., Lancaster, The Historical Society of Pennsylvania 1888). 
These important truths, sir, are far from being merely speculative. We, at this moment, speak and deliberate under their immediate and benign influence. To the operation of these truths we are to ascribe the scene, hitherto unparalleled, which America now exhibits to the world-a gentle, a peaceful, a voluntary, and a deliberate transition from one constitution of government to another. In other parts of the world, the idea of revolutions in government is, by a mournful and indissoluble association, connected with idea of wars, and all the calamities attendant on wars. But happy experience teaches us to view such revolutions in a very different light - to consider them only as progressive steps in improving the knowledge of government, and increasing the happiness of society. 59

Wilson's elaboration of the popular sovereignty rejoinder was not some newly minted, half baked, ad hoc apology for Article VII. Rather, as his immediate audience well understood, Wilson's speech built on arguments he and his allies had been crafting in Pennsylvania for almost a decade. As early as 1777 , they had articulated-and acted upon-the theory that the Pennsylvania amendment clause was not exclusive, and that popular sovereignty first principles required that the people themselves, acting in special conventions, retain the right to change their Constitution at any time and for any reason. ${ }^{60}$ "[Did not] the people ... reserve to themselves the power of approving or disapproving of the constitution, after it was framed?" asked one Pennsylvania paper in June 1777.61

b. Declarations of Rights. - Here then, was the Federalists' emphatic popular sovereignty rejoinder to the Anti-Federalists' second "illegal" gambit. Now that we understand its substance, we must investigate its source: Whence did the Federalists derive these "first principles"?

At one level, the question may be unanswerable, for at some point first principles are by definition fundamental, and fundamental by definition. Other principles derive from them, not vice-versa; they stand as the basic "rule of recognition" underlying every legal order. But on other levels-sociological and epistemological rather than ontological-we can go beneath the Federalists' confident invocations of "first principles," and see the facts and the texts on which the Federalists built, the soil in which they laid their foundation stone.

For starters, there is of course the text of 1776 Declaration of Independence, which Publius quoted, after shearing off its more limited Lockean langnage requiring a long train of government abuse. Thus Madison in Number 43 placed the accent on Jefferson's broad phraseology of a right to the people to amend "as to them shall seem most likely

59. 2 Elliot's Debates, supra note 18 , at $432-33$.

60. See Geoffrey Seed, James Wilson 123-24 (1978); and the eye-opening essay by Matthew Herrington, Popular Sovereignty in Pennsylvania 1776-1791, 67 Temp. L. Rev. (forthcoming Fall 1994) (on file with author).

61 . Wood, supra note 6 , at 444 . 
to effect their safety and happiness," which Hamilton in Number 78 paraphrased as "the right of the people to alter or abolish the established Constitution whenever they find it inconsistent with their happiness." Likewise, Wilson stressed that by legalizing the right of revolutionthrough peaceful conventions-Americans had broadened the right beyond Locke, invocable in the new world "whenever and however [the People] please" to "increas[e] the happiness of society." Wilson elaborated on this theme at length in his 1790 Lectures on Law, cleverly choosing Blackstone-who had opposed the American Revolution-rather than the more popular Locke, or a narrow reading of Jefferson's 1776 Declaration, as his foil and punching bag. ${ }^{62}$ James Iredell's remarks in the North Carolina ratifying convention also sounded this theme:

In other countries, they suppose the existence of original compact, and infer that if the sovereign [king] violates his part of it, the people have a right to resist. If he does not, the government must remain unchanged, unless the sovereign consents to an alteration. In America, our governments have been clearly created by the people themselves. The same authority that created can destroy; and the people may undoubtedly change the government, not because it is ill exercised, but because they conceive another form will be more conducive to their welfare. ${ }^{63}$

As South Carolina's Thomas Tudor Tucker put the point in 1784, in what Gordon Wood has described as "one of the most prescient and remarkable pamphlets written in the Confederation period": 64

[In America] tumultuous proceedings are as unnecessary as they would be improper and ineffectual. Other means are in our hands, as much preferable as good order is to confusion .... [Whenever the people want to cliange their constitution] it is entirely in their power to effect it without the smallest disturbance. ${ }^{65}$

Clearly, then, the Federalists' first principles pointed to the text of the Declaration, but just as clearly, they played up its popular sovereignty strains while playing down its more traditional Lockean overtones. (And if we focus on the Declaration as an act-triggering a violent revolution without taking a vote of "the People"-the Lockean dimension looms large.) The Federalists' interpretation was plausible, but needed additional support. From where?

62. See 1 The Works of James Wilson, supra note 9, at 77-79 ("[O]ne great principle, the vital principle ... is . . . that the supreme or sovereign power of the society resides in the citizens at large; and that, therefore, they always retain the right of abolishing, altering, or amending their constitution, at whatever time, and whatever manner, they shall deem it expedient."). See also id. at 317 (similar). For remarkably similar langnage from an AntiFederalist, see Letter from Samuel Adams to John Adams (Nov. 20, 1790), in 6 Works of John Adams (Charles Francis Adams ed., Boston, Little Brown \& Co. 1851).

63. 4 Elliot's Debates, supra note 18, at 229-30.

64. Wood, supra note 6 , at 280.

65. Id. at 343 (quoting Tucker's 1784 pamphlet, Conciliatory Hints, Attempting by a Fair State of Matters, to Remove Party Prejudice). 
Recall once again Madison's precise, lawyerly response to Carroll: "It was a principle in the Bills of rights, that first principles might be resorted to." Madison was of course not referring to what we today call "the Bill of Rights"- the first set of amendments to the federal Constitution-for that Bill was not even proposed until 1789 . What then did he have in mind? At one level and on one reading, the bill of rights of each state. And when we closely examine the various bills of rights and declarations of rights issuing from the states between 1776 and 1790, we will see a dramatic pattern: Each state had explicitly endorsed at least one statement-and in many cases several-that established popular sovereignty as that state's legal cornerstone. These formulations both overlapped and varied. To ease exposition, I shall quote in full the major texts from major states, and relegate to footnotes citations to and quotations from copycat and counterpart language from each sister state.

Here are the opening chords of Virginia's Declaration of Rightsthe flrst and most influential of all the state declarations, adopted in June 1776, one month before Jefferson's Declaration:

A declaration of rights made by the representatives of the good people of Virginia, assembled in full and free convention; which rights do pertain to them and their posterity, as the basis and foundation of government.

... SEC. 2. That all power is vested in, and consequently derived from, the people; that magistrates are their trustees and servants, and at all times amenable to them.

SEC. 3 ... of all the various modes and forms of government, that is best which is capable of producing the greatest degree of happiness and safety.... [W] hen any government shall be found inadequate or contrary to these purposes, a majority of the community hath an indubitable, inalienable, and indefeasable right to reform, alter, or abolish it, in such manner as shall be judged most conducive to the public weal. 66

In August 1776, Pennsylvanians promulgated a similar Declaration of Rights:

III. That the people of this State have the sole exclusive and inherent right of governing and regulating the internal police of the same.

IV. That all power being originally inherent in, and consequently derived from, the people; therefore all officers of government, whether legislative or executive, are their trustees and servants, and at all times accountable to them.

V. ... [T] hat the community hath an indubitable, unalienable and indefeasible right to reform, alter, or abolish government in such manner as shall be by that community judged most conducive to the public weal. ${ }^{67}$

66. Va. Const. of 1776 (Declaration of Rights), pmbl., §§ 2-3 (emphasis added).

67. Pa. Const. of 1776 (Declaration of Rights) arts. III-V. See Wayne Township [Pennsylvania] Petition (Mar. 1, 1788), reprinted in 2 Documentary History of the 
Three months later came a Declaration of Rights from Maryland:

I. That all government of right originates from the people .... II. That the people of this State ought to have the sole and exclusive right of regulating the internal government and police thereof.

... IV. That all persons invested with the legislative or executive powers of government are the trustees of the public, and, as such, accountable for their conduct; wherefore, whenever the ends of government are perverted, and public liberty manifestly endangered, and all other means of redress are ineffectual, the people may, and of right ought, to reform the old or establish a new government. ${ }^{68}$

Consider next the Declaration of Rights of the Massachusetts Constitution of 1780:

- IV. The people of this commonwealth have the sole and exclusive right of governing themselves as a free, sovereign, and independent state....

$\mathrm{V}$. All power residing originally in the people, and being derived from them, the several magistrates and officers of government, vested with authority, whether legislative, executive, or judicial, are their substitutes and agents, and are at all times accountable to them.

... VII. [T] he people alone have an incontestable, unalienable, and indefeasible right to institute government; and to reform, alter, or totally change the same, when their protection, safety, prosperity, and happiness require it. 69

And so it went, more or less, in each of the other nine states. Delaware's Declaration of Rights in September 1776 presaged neighbor Maryland's, though Delaware featured extra language emphasizing that the ends of government might well be threatened by "the Legislative"clearly, part of the Government-triggering a right of "the people" to alter or abolish. ${ }^{70}$ In December 1776, North Carolina copied Virginia's and Maryland's general popular sovereignty language, ${ }^{71}$ while omitting any specific declaration of the obvious corollary right to alter and abolish. Georgia, South Carolina, and New Jersey featured general popular sovereignty language; ${ }^{72}$ while Connecticut and New Hampshire tracked their

Ratification of the Constitution 716, 717 (Merrill Jensen ed., 1976) ("That as the [state] Constitution expressly declares that the people have a right to change, alter or abolish their form of government when they think it will be conducive to their interest or happiness, your petitioners believe there is ample provision made for any change that may be occasioned by adopting the proposed Federal Constitution.").

68. Md. Const. of 1776 (Declaration of Rights), arts. I, II, IV.

69. Mass. Const. of 1780 , pt. I, arts. IV, V, VII.

70. See Del. Const. of 1776 (Declaration of Rights), $\S \S 1,4,5$.

71. See N.C. Const. of 1776 (Declaration of Rights), art. I (condensing Virginia's Section 2); id. art. II (echoing Maryland's article II verbatim).

72. See Ga. Const. of $1777 \mathrm{pmbl}$. ("We, therefore, the representatives of the people, from whom all power originates, and for whose benefit all government is intended, ... do ordain and declare ..."); S.C. Const. of 1776, pmbl. ("[S]ome mode [of government] 
Massachusetts neighbor in declaring "the people" of the state "sovereign" and "independent" with a right to "governing themselves."73 New Hampshire also went on to echo Maryland's specific language about the right of "the people" to "reform the old, or establish a new government."74 New York quoted Jefferson's Declaration word for word; and added that "no authority shall ... be exercised over the people ... of this state but such as shall be derived from and granted by them." 75 Finally, even Rhode Island, whose government simply continued operating under its Crownissued charter throughout the confederation period, emphatically endorsed popular sovereignty and its implications in its 1790 ratifying convention, which declared: "That the powers of government may be reassumed by the people whenever it shall become necessary to their happiness."76 As the Federalist statesman and historian David Ramsay gushed in his 1791 History of the American Revolution:

It is true, from the infancy of political knowledge in the United States; there were many defects in their [state] forms of government; but in one thing they were all perfect. They left the people in the power of altering and amending them, whenever they pleased. ${ }^{77}$

At one level and on one reading, Madison's lawyerly response to Carroll can be understood as follows: "Your own Maryland Bill of rights explicitly affirms the first principle of popular sovereiguty, and its logical corollary, the right of the people to alter or abolish. Under Maryland law, properly understood, the Maryland amendment clause is not exclusive; for if it were, it would violate this Maryland-declared right of the people-it empowers Government, and not the people, to amend." But this level and reading are too narrow. Madison's lawyerly response was intended as general, not Maryland-specific. Yet not every state featured language as explicit as Maryland's; indeed, Rhode Island's clearest exposition came in 1790, three years after the Madison-Carroll exchange. And even Maryland's language itself featured some Lockean overtones. Indeed, the very contrast between Maryland's Declaration and Virginia's

should be established by common consent, and for the good of the people, the origin and end of all governments ..."); N.J. Const. of 1776, pmbl. (" $[A] 11$ the constitutional authority ever possessed by the kings of Great Britain over these colonies, or their other dominions, was, by compact, derived from the people, and held of them, for the common interest of the whole society.").

73. See Connecticut Declaration of Rights, 1776 pmbl., in 1 Bernard Schwartz, The Bill of Rights: A Documentary History 289 (1971); N.H. Const. of 1784 (Declaration of Rights) art. VII.

74. N.H. Const. of 1784, art X; see also id. arts. I, VII ("all government of right originates from people" and "[a]ll power resid[es] originally in" and "deriv[es] from the people").

75. N.Y. Const. of 1777 , pmbl., art. I.

76. 1 Elliot's Debates, supra note 18, at 334.

77. 1 David Ramsay, History of the American Revolution 355 (1968 Russell \& Russell (Athenian House) reprint of London ed. of 1793) (1st edition quoted in Wood, supra note 6 , at 613-14). 
broader formulation might seem to undercut Madison. If the various state declarations were legislative codes, then we might well read them narrowly, under principles of expressio unius. North Carolina's omission of any specific right to alter or abolish language might take on special significance; likewise with Maryland's less expansive formulation than Virginia's; and so on.

But these state declarations were emphatically not legislative codes. They did not claim to create new rights but to declare ones the people already had, in reason or custom or both. ${ }^{78}$ By their very nature, not all the rights of the people could be specified, and so it would be silly to make too much of a silence or omission-especially if omitted language merely clarified a logical corollary of explicit language, as the right of the people to alter or abolish logically flowed from popular sovereignty. (The later federal Ninth Amendment would explicitly confirm the silliness of reading Bills of Rights in narrow expressio unius fashion.) And broader or earlier language from state $A$ did not necessarily confirm the narrowness or newness of language from state B; on the contrary. These declarations were quasi-judicial utterances, declaring the true common law-common to all American states. The various declarations were not trying to do different things-as legislatures of different states often enact different, particular statutes-but trying to do the same thing: correctly define and declare the true contours of various rights. If state A's declaration was actually a better or clearer statement of a truth that other declarations were also haltingly seeking to express, then state A's declaration was a positive precedent for the other states, not an expressio unius stumbling block. The obvious modern day analogy is the particularly persuasive and well reasoned common law opinion of well respected judge $X$ from state $A$, which is surely entitled to great weight in sister states. ${ }^{79}$

And this is exactly how Madison himself seems to have thought about the matter; and for him, on this issue at least, the best articulation of the right came from his own Virginia-the largest state, with the first and most influential set of declarations, authored by the widely respected George Mason. For when Madison said to Carroll-"It was a principle in the Bills of rights, that first principles might be resorted to"-he was invoking the particular wording of another well-known provision of Mason's celebrated Virginia Declaration: "Sec. 15. That no free government, or the blessings of liberty, can be preserved to any people, but by a firm adherence to justice, moderation, temperance, frugality, and virtue, and by frequent recurrence to fundamental principles." 80 The fact that Mary-

78. In the words of the Anti-Federalist pamphleteer, The Federal Farmer, "We do not by declarations change the nature of things, or create new truths." Letters from The Federal Farmer (XVI), in 2 Storing, supra note 48 , at 324.

79. For more elahoration of the "declaratory theory" of rights underlying this paragraph, see Akhil Reed Amar, The Bill of Rights and The Fourteenth Amendment, 101 Yale L.J. 1193, 1205-12 (1992).

80. Va. Const. of 1776 (Declaration of Rights) $\$ 15$ (emphasis added). 
land had no explicit counterpart in its declaration mattered little, for section 15 declared a truth applicable to all "free government" - on both sides of the Potomac. And what was true for Mason and Virginia's section 15 was likewise true of their section 3; it too, counted as a serious precedent for all the other states. How, indeed, could it be otherwise if the section 3 right of the people to alter or abolish was, as Virginia declared, "indubitable, inalienable, and indefeasible"? At the very least, a contrary inference should require an emphatically clear, explicit rejection of this right from any sister state that found Virginia's broad formulation faulty and sought to narrow it. None of the states came close to this, unless the reader falls into the expressio unius trap.

c. Majority Rule. - The broad Federalist rejoinder, then, stressed that, as a matter of first principles, the people of each state retained the legal right to alter their government at any time and for any reason. Clearly this was so in any state that lacked any explicit constitutional clause setting out a mode of amendment. And in those states that did have such a clause-Pennsylvania, Maryland, and Massachusetts, for example 81 - the clause simply added an additional mode of amendment without in any way limiting the people's pre-existing background right to alter or abolish. Any other reading of the state amendment clause would violate the state's own first principles, embodied in the state's own declaration of rights, and those of sister states.

One clever counterploy to this Federalist rejoinder would try to read the various state amendment clauses not as excluding, but as implementing-exclusively! - the people's right to alter or abolish. But this clever counterploy fails. The Maryland amendment clause empowered ordinary Government-the legislature-and not the people themselves. ${ }^{82}$ In both Massachusetts and Pennsylvania, the amendment clause specified certain dates for amendment-in Massachusetts, 1795; in Pennsylvania, every seven years-whereas first principles required that the people be able to alter or abolish at any time. ${ }^{83}$

Sensing this, the pamphleteer who played the illegality gambit in Massachusetts explicitly conceded, as we have already noted, that 1795 was not exclusive, and need not be read as such. But by similar grammatical logic, the entire amendment clause was nonexclusive; its date was syntactically intertwined with its other rules, and so the concession gave away the game.

But far more fundamentally, the Massachusetts clause could not be considered as implementing first principles since the clause expressly required a supermajority of popular support-and so too, with the

81. See also Del. Const. of 1776, art. 30; Ga. Const. of 1777, art. LXIII; S.C. Const. of 1778, art. XIIV; N.H. Const. of 1784, Pt. II, last para.

82. So, too, in Delaware and South Carolina.

83. See supra notes $62-65$ and accompanying text. 
Pennsylvania clause ${ }^{84}$-whereas first principles required that a simple majority of the people be empowered to alter or abolish. This simple majority could occur in a "convention" of the People; popular sovereignty theory, for good reasons, ${ }^{85}$ sharply distinguished special conventionschosen in a special election of the entire polity, ${ }^{86}$ for the sole purpose of effecting constitutional change-from ordinary everyday legislatures (often chosen by a more restricted electorate), and assimilated these special convention assemblies to "the people" themselves. The simple majority rule principle might even be consistent with a requirement that the people (or conventions) vote on two separate occasions, to ensure that the majority had truly deliberated, and truly intended the proposed alteration. But, first principles clearly demanded that a simple, deliberate majority of the polity-fifty percent plus one-would suffice. The Massachusetts and Pennsylvania clauses clearly failed this requirement, and thus had to be viewed as nonexclusive as a matter of first principles.

The majority rule corollary of popular sovereignty and the right to alter or abolish appeared most obviously in George Mason's celebrated Virginia Declaration, with its explicit emphasis on the "indubitable, unalienable, and indefeasible" right of "a majority of the community." No other state declaration addressed the issue explicitly, and clearly none explicitly took issue with Virginia's Declaration.

This last point is not some lawyer's trick to prevail only by shifting the burden of proof. In the 1780s the special status of majority rule was extraordinarily well understood. Both as a general default rule in the absence of specific language to the contrary, and as a specific corollary of popular sovereignty, it literally went without saying in a variety of declarations precisely because it was so obvious. Thus, Jefferson's 1776 Declaration spoke only of "the riglit of the People to alter or abolish" without specifying a precise voting rule; but clearly Jefferson believed that popular sovereignty, best understood, meant majority rule-it went without saying. Thus, in a now-famous letter to James Madison in December 1787, he wrote:

After all, it is my principle that the will of the Majority should always prevail. If they approve the proposed [constitution,] I shall concur in it chearfully, in the hopes that they [i.e., a Majority] will amend it whenever they shall find it work wrong. ${ }^{87}$

84. New Hampshire's amendment clause, based on the Massachusetts model, also had this defect and likewise specified a certain date for amendment.

85. I have explored these reasons in detail elsewhere. Simply put, there are far fewer agency costs between convention and people-much like today's Presidential electors. See Amar, supra note 3, at 1094-95.

86. See supra note 8 .

87. Letter from Thomas Jefferson to James Madison (Dec. 20, 1787), in The Portable Thomas Jefferson 432 (Merrill D. Peterson ed., 1975). 
In his first Inaugural Address, Jefferson described "absolute acquiescence in the decisions of the majority" as "the vital principle of republics." 88 And in yet another now-famous letter, he wrote:

[The people] alone have a right to direct what is the concern of themselves alone, and to declare the law of that direction; and this declaration can only be made by their majority. That majority, then, has a right to depute representatives to a convention, and to make the Constitution what they think will be the best for themselves. ${ }^{89}$

Indeed Jefferson believed majority rule to be a logical corollary of equality, which the Declaration had proclaimed as a "self-evident truth":

The first principle of Republicanism is, that the lex majoris partis is the fundamental law of every society of equal rights. To consider the will of the society enounced by the majority of a single vote as sacred as if unanimous is the first of all lessons of importance..$^{90}$

That those views of the Declaration's writer were widely shared by its readers is nicely illustrated by Joseph Story's landmark Commentaries on the Constitution, where the great Associate Justice interpolated as follows:

The declaration of independence ... puts the doctrine on its true grounds. ... Whenever any form of government becomes destructive of these ends, it is a right of the people (plainly intending, the majority of the people) to alter, or to abolish it ....91

These views were near universal in the 1780 s, for anyone who had read Locke knew that majority rule stood as a basic default principle of all assemblies. ${ }^{92}$ But more concretely, Americans understood the unique status of majority rule for implementing popular sovereignty and the right to alter or abolish. Thus, as early as 1777 we find Pennsylvanians expressly attacking the exclusivity of the Council of Censors. Though specially elected by the people for the express purpose of effecting consti-

88. Thomas Jefferson, First Inaugural Address (Mar. 4, 1801), in The Portable Thomas Jefferson, supra note 87, at 293.

89. Letter from Thomas Jefferson to Samuel Kercheval (July 12, 1816), in The Portable Thomas Jefferson, supra note 87 , at 560 .

90. Letter from Thomas Jefferson to Baron F. H. Alexander Von Humbolt (June 13, 1817), in 10 The Writings of Thomas Jefferson 89 (Paul Leicester Ford ed., New York, G.P. Putnam's Sons 1899).

91. 1 Joseph Story, Commentaries on the Constitution of the United States $\$ 330$ (Boston, Hilliard, Gray \& Co. 1833) (parenthesis in original).

92. See Locke, supra note 15 , at $\S 96$; see also Jefferson, Notes on the State of Virginia, in The Portable Thomas Jefferson, supra note 87, at 171 ("Lex majoris partis [is] founded in common law as well as common right. It is the natural law of every assembly of men.") (citing Brooke, Hakewell, and Pufendorf); Wilmoore Kendall, John Locke and the Doctrine of Majority-Rule 112 (1959); Wood, supra note 6, at 62-64 (citing Bernard Wishy, John Locke and the Spirit of '76, 73 Pol. Sci. Q. 413, 413-25 (1958)); Walter Berns, The Constitution as a Bill of Rights, in How Does the Constitution Secure Rights? 50, 58-59 (Goldwin \& Schambra eds., 1985). For still more documentation, see Russell L. Caplan, Constitutional Brinksmanship 120-21 (1988). 
tutional change-and thus in some respects like a convention-the Council was malapportioned and operated under a two-thirds rule. A convention was needed, Wilson and his allies argued, precisely because it would better reflect "the opinions of the majority."

To pluck out only a few of the countless examples of the point from Gordon Wood's magisterial account of the Confederation period,,$^{94}$ here are a couple of essays from the 1783 Connecticut Courant:

[A]s the people had all power originally in themselves, so they still retain it, to such a degree, that a majority of the people at large, have a right to reverse and annul every act and contract of all the legislatures on the continent. ${ }^{95}$

[It is] impossible [for the Legislature] to impose an irrevocable act contrary to the majority of the people, from whom they received their power. ${ }^{96}$

And here is Samuel West in lis 1776 Massacluusetts election sermon:

[I] $t$ is the major part of a community that have the sole right of establishing a constitution and authorizing magistrates; and consequently it is only the major part of the community that can claim the right of altering the constitution, and displacing the magistrates. ${ }^{97}$

Majority rule continued to hold sway as a self-evident corollary of popular sovereignty throughout the deliberations over the federal Constitution. At Philadelphia, Elbridge Gerry-another signer of the Declaration of Independence-casually remarked that of course any convention called by state governments under the rules of Article $V$ would operate by majority rule, even though the text of Article $V$ nowhere specified this. ${ }^{98}$ (Once again, it went without saying.) And in another speech at Philadelphia, Gouverneur Morris mentioned in passing-since the point was self-evident-that "the Constitution of a particular State may be altered by a majority of the people of the State."99

During the ratification period, Federalist Noah Webster's pamphlet described as "a doctrine as universally received, as any intuitive truth" the proposition "that the opinions of a majority must give law to the whole State." 100 Similarly, Arclibald Maclaine declared in the North Carolina ratifying convention that "because all power is in the people" they lad "the authority ... to devise such a government as a majority of them thinks will promote their happiness .... They, sir, have formed their

93. Wood, supra 6 , at 443-45.

94. For further examples, see id. at $274,284,286,288,343,412,506,533$.

95. Id. at 368 .

96. Id. at 384 .

97. Id. at 307 .

98. 2 Farrand, supra note 28 , at $557-58$.

99. Id. at 92.

100. Noah Webster, An Examination into the Leading Principles of the Federal Constitution, by a Citizen of America, in Pamphlets on the Constitution of the United States 25, 30 (Paul L. Ford ed., n.p. 1888) (emphasis in original). 
state governments and can alter them at pleasure."101 And Publius was consistent and unequivocal on this point. In the Federalist Number 21, Hamilton wrote that the federal Constitution's Republican Government Clause "could be no impediment to reforms of the State constitutions by a majority of the people in a legal and peaceable mode. This right would remain undiminished." 102 To the same effect was Madison in Number 39:

[T] he majority [of the whole people] in each State must bind the minority [in framing a Constitution] .... .

... Were [the Constitution] wholly national, the supreme and ultimate authority would reside in the majority of the people of the Union; and this authority would be competent at all times, like that of a majority of every national society to alter or abolish its established government. ${ }^{103}$

Even Anti-Federalists shared this belief in majority rule as a clear corollary of popular sovereignty. Thus we find the very same Pennsylvania Anti-Federalists who tried to play the "illegal" card appearing to concede only a paragraph later that perhaps the Pennsylvania Constitution could be altered if "a majority of the people should evidence a wish for such a change."104 (The Anti-Federalists denied that such a majority had evidenced such a desire, pointing to the low voter turnout in electing convention delegates. The obvious Federalist counterargnment would be that in a properly called election, a majority of those voting - not of those eligible-should prevail.) ${ }^{105}$ So too, the Federal Farmer-perhaps the leading Anti-Federalist pamphleteer-wrote that "[i]t will not be denied,

101. 4 Elliot's Debates, supra note 18 , at 161 .

102. The Federalist No. 21, at 140 (Alexander Hamilton) (Clinton Rossiter ed., 1961); see also id. No. 22, at 146 (Alexander Hamilton) (declaring that "fundamental maxim of republican government ... requires that the sense of the majority should prevail"); id. No. 58, at 361 (James Madison) (asserting that majority rule is "the fundamental principle of free government").

103. Id. No. 39, at 244, 246 (James Madison) (emphasis in original). As we shall see below, Madison did not believe that the Constitution was ultimately national; he believed that sovereignty could somehow be divided between state peoples and a national people. In this belief, Madison was uncharacteristically without followers-and, with good reason. See infra Part III.G.

See also The Federalist No. 40, at 251 (James Madison) (Clinton Rossiter ed., 1961) (explicitly emphasizing that Article VII ratifying conventions are governed by simple majority rule). For further evidence of Madison's acceptance of the primacy of simple majority rule, see Richard Hofstadter, The Idea of a Party System 208 (1969) (quoting 1833 Madison letter: "the vital principle of republican government is the lex majoris partis, the will of the majority").

104. The Address and Reasons of Dissent of the Minority of the Convention of Pennsylvania to Their Constituents, in 3 Storing, supra note 48, at 145-50.

105. See Amar, supra note 3 , at 1064 n.78. On the importance of a properly called election, where strict rules against force and fraud are in place, see id. at $1061 \mathrm{n.67}$. In an election not properly called by duly constituted authorities, it is much harder to argne that those who boycott the election or abstain from voting have surrendered their proxies to those who do vote. This was the crux of the matter in Dorr's Rebellion in Rhode Island in the 1840 s; see id. at 1053 n.28. For more discussion of all these issues, see Roger Sherman 
that the people have a right to change the government when the majority chuse it, if not restrained by some existing compact"106_i.e. a valid treaty. In Virginia the firebrand Patrick Henry seemed to concede that the proposed Constitution's Article V was in theory not exclusive-a point to which we shall return-but worried that in practice it would be. ${ }^{107}$ And if exclusive as a practical matter, it would, Henry argued, clearly violate first principles, for a popular majority might not prevail under it. Henry quoted Virginia's Third Declaration verbatim, stressing its commitment to simple majority rule, and labelling it "the genius of democracy." 108

Perhaps most clear and most dramatic of all were the words of the great James Wilson. In the Pennsylvania ratifying convention, he attacked the two-thirds rule of the Council of Censors, and repeated his commitment to simple majority rule in constitutional amendment. ${ }^{109}$ But his nicest formulation of the point came in his 1790 Lectures on Law in a passage that was as clear then as it is unknown now:

As to the people, however, in whom sovereign power resides, ... [f]rom their authority the constitution originates: for their safety and felicity it is established; in their hands it is clay in the hands of the potter: they have the right to mould, to preserve, to improve, to refine, and to finish as they please. If so; can it be doubted, that they have the right likewise to change it? A majority of the society is sufficient for this purpose . . . ${ }^{110}$

So much for the Founders' words. If we turn instead to their deeds, we see an even more vivid picture. Article VII as a text nowhere specified that within each state convention, a simple majority would rule. But this was the universal understanding in every state. I know of not a single leading Anti-Federalist who tried to claim that somehow, the convention should follow supermajoritarian-that is, minority veto-principles. On the contrary, men like Patrick Henry explicitly conceded that they "must submit" to the opinion of the convention "majority."111 And in state after state, Anti-Federalists in the final analysis acted on this understanding, accepting the legitimacy of the ultimate outcome. The point here, though often overlooked today, is absolutely vital, for in many states the convention vote was a squeaker: $30-27$ in New York; 187-168 in Massachusetts; 57-47 in New Hampshire; and 89-79 in Henry's own Vir-

Hoar, Constitutional Conventions: Their Nature, Powers, and Limitations 15-29, 38-57, 76 (1917).

106. Letters From the Federal Farmer (XVII), in 2 Storing, supra note 48, at 330, 336.

107. See 3 Elliot's Debates, supra note 18 , at $50-51$.

108. Id. at 49-51. See also id. at 55 (stressing simple majority rule for constitutional amendment).

109. See 2 id. at 457-58. Later, Wilson asked, "[w]ho are the majority in this assembly-Are they not the people?" Id. at 495.

110. 1 The Works of James Wilson, supra note 9, at 304 (emphasis added). For further discussion of majority rule in Wilson, see id. at 242; 2 id. at 507-09, 529.

111. See 3 Elliot's Debates, supra note 18 , at 50. 
ginia, for example. ${ }^{112}$ With so many clever and ardent folk opposed to ratification, why did no one try to make hay of the omission in the text of Article VII? Because majority rule really did go without saying. ${ }^{113}$

\section{B. The Meaning of the Constitution}

Thus the Anti-Federalists' second "illegal" gambit also failed, and properly so. But we have now reached a critical step in the proof of my "First Theorem." Though setting out merely to establish the basic legality of the act of constitution before closely parsing the text of constitution, we have in fact done much more. We have seen how that act itself reflected and embodied-self-consciously-first principles of the legal order, popular sovereignty and majority rule. Further, we have confronted various state constitutional clauses-from Maryland, Massachusetts, Pennsylvania, and elsewhere-that look remarkably like our federal Article V. At first blush, these state Article V analogues seemed to set out the exclusive mode of state constitutional amendment. But after more care-

112. Thus the key voting rule in Article VI is simple majority rule, and not supermajority rule, as might be inferred from a too casual glance at its seeming $9 / 13$ voting rule. The focus on $9 / 13$ is misleading. To begin with, this is not a true voting rule at all, since the four dissenting states would not be bound by the nine affirmative states. The true voting rule occurs within each state, where a simple majority did bind dissenters. Given that each state was sovereign prior to ratifying the Constitution, the place to look for the key voting rule is within each state, where a simple majority of the sovereign people did alter or abolish their pre-existing constitution. The $9 / 13$ provision is thus best understood as a substantive condition subsequent, modifying what, precisely, the people of each state were voting for: a new constitution if and only if eight other states agreed, so that the new scheme could achieve a workable critical mass.

113. Actually Edmund Randolph in the Virginia Convention did say something, when he thought that the Anti-Federalist minority might try to break a quorum: "[A]n idea of refusing to submit to the decision of the majority is destructive of every republican principle." 3 Elliot's Debates, supra note 18, at 597.

In a letter to a young John Quincy Adams (who would one day be President) a young William Cranch (who would one day be a federal judge and Supreme Court reporter) tried to appeal to majority rule to overcome Anti-Federalist objections rooted in the Articles of Confederation: "And respecting the violation of the 13th. Article of the ConfederationWas not that article made by the majority of the people? \& have not the majority of the people the same right to pass an Article repealing the 13th. Article." Letter from William Cranch to John Quincy Adams (Nov. 26, 1787), in 14 Documentary History of the Ratification of the Constitution, supra note 34, at 226. This argnment mismatched the Federalists' second rejoinder to the Anti-Federalists' first gambit, and Adams was apparently not persuaded. See id. at 228 (Reply Letter of December 8, 1787). Yet Adams, who early on opposed the Constitution, later seemed to echo Cranch's ode to majority rule popular sovereignty. Upon hearing of the ratification of the Constitution, young Adams wrote in his diary: "I think it my duty to submit .... In our Government, opposition to the acts of a majority of the people is rebelion to all intents and purposes." Id. at 220 (entry of Feb. 7, 1788). The timing of Adams's apparent turnaround corresponds precisely with the publication of the Federalist Nos. 39-43, which straightened out two distinct arguments young Cranch had collapsed. Published in January 1788, Number 43 explained why Massachusetts was legally free to abandon Article XIII and the Articles, and Numbers 39-40 explained why a simple majority of the Massachusetts people could alter or abolish their state constitution, in keeping with popular sovereignty first principles. 
ful inspection, we learned that these Article $\mathrm{V}$ analogues were not best read as exclusive. As a matter of first principles, the polity had retained the legal right to alter or abolish outside these analogues by simple majority vote.

And so the obvious question is, why is the same not true for Article V itself? Why does not a simple majority of the national People-for the Constitution forms one national People from the formerly distinct thirteen state peoples-retain an analogous legal right to alter or abolish its Constitution outside Article V?114 (Once again, Article V cannot be read as implementing that right, because it is both Government-driven and minoritarian; its rules may well thwart sensible constitutional changes strongly desired by a deliberate majority of the American polity.) ${ }^{115}$

A strict textualist might insist that even if this right exists as a matter of first principles, we must locate it somewhere in the text of the Constitution itself-though not necessarily within the four corners of Article Vbefore we can call this right of the people a true constitutional right separate from, but equal to, Article V.116 It is tempting to quibble with the textualist here by reminding her that all texts derive their meaning from larger historical contexts, acts, and language patterns; and that the Constitution's larger context-the very act of constitution itself, and the language of popular sovereignty in which that act was inextricably and selfconsciously embedded-made clear that majority rule popular sovereignty must be part of the Constitution. A further quibble might remind the strict textualist that we have indeed found legal texts-the thirteen state declarations-attesting to the legal (and not merely philosophical, or speculative) nature of the right of majority rule popular sovereignty; and that those texts declared legal truths believed applicable, inalienable, and indubitable in all free governments.

114. I intentionally gloss over some important federalism issues here, which I have addressed in considerable detail elsewhere, and to which I shall return at the end of this essay.

115. See supra notes 8-9 and accompanying text. We should not be led astray by Article V's reference to state ratifying conventions. After 1788, the relevant sovereign People was not the people of each state, but the People of the United States. See infra notes 117-I18 and accompanying text; Part III.G. Indeed, Article V is itself strong evidence that after ratification of the federal Constitution, the people of, say, Virginia, would no longer be sovereign; for if sovereign, Virginia could not be bound by any later amendment the Virginia people rejected in convention assembled, even one ratified by every other state convention. Yet Article $V$ clearly says that Virginia would be bound in this situation. Thus, the dramatic contrast between Article VII's treatment of state conventions-where no state convention could bind a sister state-and Article V's treatment marks the shift upon ordainment and establishment of the U.S. Constitution from state to national popular sovereignty achieved by a "Union" (or merger) of previously separate states.

Article $\mathrm{V}$ ratifying constitutions are thus not the sovereign people, but subordinate assemblies interchangeable with state legislatures for Article $V$ purposes.

116. In fact this constitutional right is in certain respects even higher than Article $V$, though inside the Constitution. See infra Part III.B. 
But let us put aside such quibbles, for there are indeed clear texts in the United States Constitution-texts outside Article V but very much inside (indeed, fundamental to) the Constitution, understood as a unified document-that confirm the right we have rediscovered. When properly read, these texts say the very same thing and serve the very same function at the national level as the state declarations in the context of state Article $\mathrm{V}$ analogues.

1. The Preamble. - Begin at the beginning. Do not the words-"We the People of the United States ... do ordain and establish this Constitution"-say it all? What We, acting by simple majority in convention assembled (see Article VII), have ordained and established, cannot We, acting similarly, alter or abolish? Of course, because the Constitution formed previously separate state peoples into one continental peopleAmericans! - by substituting a true (and self-described) Constitution for a true (and self-described) league, the relevant majority after ordainment and establishment should be national, not state by state, as it was before ordination and establishment, under Article VII. An easy modern day analogy comes from corporate law: company A and company B agree to merge, with the merger approved by lawful majorities of each company's shareholders; but after merger, we look to the lawful majority of shareholders of the newly formed company, United A\&B. ${ }^{117}$ (And we should not forget that Massachusetts, New Jersey, and Connecticut had themselves each been formed by mergers of previously separate colonies, prior to the American Revolution.) ${ }^{118}$ To be sure, the Constitution redefined the relevant polity, but that redefinition cannot change the basic nature of popular sovereiguty. If it did, no state prior to 1787 could have been grounded on popular sovereignty, for every new day brought a slight redefinition of the polity, with some voters dying and others coming of age, with western borders being relentlessly pushed back and new settlers brought in.

But of course, every text finds itself embedded in an historical context. Did the Founders themselves recognize the Preamble as a textual declaration of popular sovereignty and the people's right to alter or abolish? Indubitably. For Publius, no federal Bill of Rights was necessary because, as Hamilton wrote in Number 84:

Here, in strictuess, the people surrender nothing; and as they retain everything, they have no need of particular reservations, "WE THE PEOPLE of the United States, to secure the blessings of liberty to ourselves and our posterity, do ordain and establish this Constitution for the United States of America." Here is a [clear] recognition of popular rights . ...119

117. See supra note 115; infra Part 1II.G.

118. See 1 Farrand, supra note 28, at 462 (remarks of Nathaniel Ghoram).

119. The Federalist No. 84, at 513 (Alexander Hamilton) (Clinton Rossiter ed., 1961) (emphasis in original). 
And what "right" was more "popular" than popular sovereignty? Recall once again Iredell's speech in the North Carolina ratifying convention yoking the right to ordain and establish with the right to alter or abolish: "In America, our governments have been clearly created by the people themselves. The same authority that created can destroy; and the people may undoubtedly change the government." 120 And listen with special care to the man who wrote the first draft of the Preamble, James Wilson:

[T] he leading principle in the politics [sic], and that which pervades the American constitutions, is, that the supreme power resides in the people. This Constitution ... opens with a solemn and practical recognition of that principle: - "We, the people of the United States, in order to form a more perfect union, establish justice, \&cc., do ordain and establish this Constitution for the United States of America." It is announced in their name-it receives its political existence from their authority: they ordain and establish. What is the necessary consequence? Those who ordain and establish have the power, if they think proper, to repeal and annul. ${ }^{121}$

And as we know from Wilson's other remarks, Wilson clearly meant here majority rule popular sovereignty.

In yet another remarkable speech, the great lawyer and Virginia convention President Edmund Pendleton invoked the Preamble as proof that the people would retain a legal right to alter or abolish. Article V, said Pendleton, simply set out one "easy and quiet" mechanism of amendment; but because it was Government-driven, it could not be exclusive:

We, the people, possessing all power, form a government, such as we think will secure happiness: and suppose, in adopting this plan, we should be mistaken in the end; where is the cause of alarm on that quarter? In the same plan we point out an easy and quiet method of reforming what may be found amiss. No, but, say gentlemen, we have put the introduction of that method in the hands of our servants, who will interrupt it from motives of self-interest. What then? .. . Who shall dare to resist the people? No, we will assemble in Convention; wholly recall our delegated powers, or reform them so as to prevent such abuse; and punish those servants who have perverted powers, designed for our happiness, to their own emolument. ${ }^{122}$

The leader of the Virginia Anti-Federalists, Patrick Henry, appeared to concede Pendleton's legal analysis, but predicted that a federal standing army would prevent the people from ever exercising their legal right to "assemble" in Convention. ${ }^{123}$ In light of the Pendleton-Henry exchange, the declaration issued by the entire Virginia Convention to accompany its

120. 4 Elliot's Debates, supra note 18 , at 230.

121. 2 id. at $434-35$ (emphasis in original).

122. $3 \mathrm{id}$. at 37 . Logic suggests that Pendleton is referring here to a convention outside Article V, see Amar, supra note 3, at 1056-57.

123. See 3 Elliot's Debates, supra note 18, at 51 . 
ratification takes on added significance: " $[T]$ he powers granted under the Constitution, being derived from the people of the United States, may be resumed by them, whensoever the same shall be perverted to their injury or oppression." 124

And if we need still further proof, we shall find it in the first Congress, where James Madison proposed various "declaratory and restrictive" amendments to the Constitution. ${ }^{125}$ Although our federal "Bill of Rights" was eventually tacked on to the end of the original document, Madison initially proposed to interweave new clauses directly into the original fabric. One of these proposals was to append a prefix to the Preamble which included the following: "That the people have an indubitable, unalienable and indefeasible right to reform or change their Government . . . ."126 Not one Representative quarrelled with Madison on the substance of this claim, but the prefix was eventually dropped precisely because its detractors deemed it redundant, given the broad meaning of the Preamble itself. Thus James Jackson of Georgia-whose own state constitution merely contained general popular sovereignty langnage ${ }^{127}$-declared that the Preamble's "words, as they now stand, speak as much as it is possible to speak; it is a practical recognition of the right of the people to ordain and establish Governments, and is more expressive than any other mere paper declaration."128 Likewise John Page argued that the original Preamble "had the neatness and simplicity, while its expression was ... most forcible." ${ }^{129}$ John Vining from Delaware went even further:
A bill of rights was unnecessary in a Government deriving all its powers from the people; and the constitution enforced the prin- ciple in the strongest manner by the practical declaration pref- aced to that instrument; he alluded to the words, "We the people do ordain and establish." 130

Finally, consider the words of Roger Sherman, another member of the select six-man club of Declaration and Constitution signers:

The people of the United States have given their reasons for doing a certain act. Here we propose ... to let them know that they had a right to exercise a natural and inherent privilege, which they have asserted in the solemn ordination and establishment of the constitution. Now, if this right is indefeasible, and the people have recognized it in practice, the truth is better asserted then it can be by any words whatever. The words "We the people" in the original constitution, are as copious and expres-

124. 1 id. at 327 .

125. See 2 Schwartz, supra note 73 , at 1164 .

126. Id. at 1026.

127. See supra note 72 .

128. 2 Schwartz, supra note 73 , at 1072.

129. Id. at 1077. Though Page thought the Preamble "no part of the Constitution," id., his views on that point were incorrect and atypical.

130. Id. at 1041. 
sive as possible; any addition will only drag out and lengthen the sentence without illuminating it. ${ }^{131}$

2. The Ninth and Tenth Amendments. - Closely related to the Preamble were words that eventually became the Ninth and Tenth Amendments:

The enumeration in the Constitution, of certain rights, shall not be construed to deny or disparage others retained by the people.

The powers not delegated to the United States by the Constitution, nor prohibited by it to the states, are reserved to the States respectively, or to the people. ${ }^{132}$

Conventional wisdom misses this close triangular interrelation. The Ninth is said to be about unenumerated individual rights, like personal privacy; the Tenth, about federalism; and the Preamble, about something else again. But look again at these texts. All are at their core about popular sovereignty. All, indeed, explicitly invoke "the people." In the Preamble, "We the people . . d do" exercise our right and power of popular sovereignty, and in the Ninth and Tenth "the people" expressly "retain" and "reserve" our "right" and "power" to do it again. If the Ninth is mainly about individual rights, why does it not speak of individual "persons" rather than the collective "the people"? If the Tenth is only about states' rights, why does it stand back-to-back with the Ninth, and what are its last three words doing there, mirroring the Preamble's first three?

The legislative history of these amendments confirms their close interrelations with each other and with the Preamble, and their obvious implications for the people's right to alter or abolish, as revealed by even a casual glance at the initial formulations of these principles in the Virginia and New York ratifying conventions. First, Virginia:

$[T]$ he powers granted under the Constitution, being derived from the people of the United States, may be resumed by them, whensoever the same shall be perverted to their injury or oppression, and that every power not granted thereby remains with them, and at their will; that, therefore, no right ... can be cancelled, abridged, restrained, or modified by [the U.S. government] except in those instances in which power is given by the Constitution for those purposes. ${ }^{133}$

Next, New York:

That all power is originally vested in, and consequently derived from, the people, and that government is instituted by them for their common interest, protection and security ....

That the powers of government may be reassumed by the people whensoever it shall become necessary to their happiness;

131. Id. at 1077.

132. U.S. Const. amends. IX, X.

133. 1 Elliot's Debates, supra note 18, at 327. Leading works on the Tenth Amendment almost never mention this key text, and often gloss over the words "the people" in the Tenth Amendment. 
that every power, jurisdiction, and right, which is not by the said Constitution clearly delegated to the Congress of the United States, or the departments of the government thereof, remains to the people of the several states, or to their respective state governments, to whom they may have granted the same; and that those clauses in the said Constitution, which declare that Congress shall not have or exercise certain powers, do not imply that Congress is entitled to any powers not given by the said Constitution; but such clauses are to be construed either as exceptions to certain specified powers, or as inserted merely for greater caution. ${ }^{134}$

Recall that Hamilton prefaced his discussion of the Preamble in The Federalist Number 84 with the words "Here, in strictness the people... retain everything, [so] they have no need of particular reservations." ${ }^{135} \mathrm{Re}-$ call also Wilson's Pennsylvania convention speech that "supreme . . . power remains in the people"136 — a point he formulated a bit later as follows: The people "never part with the whole" of their "original power ... and they retain the right of recalling what they part with. ... [T] $\mathrm{T}$ he citizens of the United States may always say, WE reserve the right to do what we please." 137

Finally, consider the remarks of South Carolina Representative Thomas Tudor Tucker in the First Congress, when an early version of the Tenth Amendment was under discussion:

Mr. Tucker proposed to amend the proposition, by prefixing to it "all powers being derived from the people." He thought this a better place to make this assertion than the introductory clause [i.e. Preamble] of the constitution, where a similar sentiment was proposed by the committee. ${ }^{138}$

Eventually, of course, the same point was made by the Amendment's last three words. ${ }^{139}$

3. The Right of the People to Assemble. - The popular sovereignty motif sounded by the words "the People" in the Preamble and Amendments Nine and Ten should attune us to the words and the music elsewhere in the Constitution. And once attuned, we hear another clear affirmation of the first principles of majority rule popular sovereignty: the First Amendment "right of the people to assemble."

As Gordon Wood has observed, "conventions ... of the people ... were closely allied in English thought with the people's right to assem-

134. Id.

135. Quoted supra text accompanying note 119 (emphasis added).

136. Quoted supra text accompanying note 58 (emphasis in original).

137. 2 Elliot's Debates, supra note 18, at 437 (emphasis added). Note how Wilson's capital WE ties back to the Preamble, while his other language anticipates the Ninth and Tenth Amendments.

138. 2 Schwartz, supra note 73, at 1118.

139. The precise chronology of this insertion is uncertain. See Edward Dumbauld, The Bill of Rights And What It Means Today 42 n.32 (1957). 
ble"140_thus, for example, we find Blackstone describing how in 1688 the British people, through Parliament "assemble[d]" in "Convention."141 And in revolutionary America, we almost invariably find the ideas and words "people," "assemble," and "convention" tightly clustered in discussions of popular sovereignty. ${ }^{142}$ Indeed, we have already seen several of these countless clusters. Recall, for example, the opening words of the Virginia Declaration of 1776 ; $^{143}$ the wording of the Philadelphia Convention's initial version of Article VII; ${ }^{144}$ and Edmund Pendleton's pointed phrase that if dissatisfied with Article V, "the people" will "assemble in convention"145 - clustered words repeated by Patrick Henry in his apparent concession of the point. ${ }^{146}$ Consider also the clear statement of AntiFederalist John Smilie in the Pennsylvania Convention:

I take it, sir, that even after this Convention shall have agreed to ratify the proposed plan, if the people on better information and maturer deliberation should think it a bad and improper form of government, they will still have a right to assemble another body [i.e., a Convention] ... to abrogate this federal work so ratified ... [So] a worthy member of the late Convention [James Wilson] admits when he says, the people have at all times a power to alter and abolish government .... ${ }^{147}$

Members of the first Congress clearly understood all this in 1789 , as evidenced by a casual reference in Congress itself to the "assembling of a convention." 148 Thus, a core meaning of "the right of the people to assemble" in 1789 was their right to assemble in convention. ${ }^{149}$ To be sure this was not the only meaning, for the text radiated beyond this core, just as the text of the Ninth Amendment radiated beyond the core right of the people to popular sovereignty. But there is no doubt that in both places, the words "the people" do indeed mean-at least-just that.

\section{Objections and Conclusions}

We have now completed the initial proof of my "First Theorem." Just as first principles and various state declarations required us to rethink and ultimately reject the seeming exclusivity of state analogues to Article

140. Wood, supra note 6 , at 312 .

141. See 1 William Blackstone, supra note 25, at 153-54.

142. Further documentation appears in Amar, supra note 3, at 1058-60; and Akhil Reed Amar, The Bill of Rights as a Constitution, 100 Yale L.J. 1131, 1152-55 (1991).

143. See supra text accompanying note 66 .

144. See supra text accompanying note 45 .

145. See supra text accompanying note 122 .

146. See supra text accompanying note 123 .

147. 2 Documentary History of the Ratification of the Constitution, supra note 34, at 376 (emphasis added) (final brackets in original).

148. 2 Schwartz, supra note 73, at 1022 (remarks of John Page).

149. See, e.g., Barron v. Baltimore, 32 U.S. (7 Pet.) 243, 249-50 (1833) (finding that "a convention could have been assembled" to amend state constitutions); McCulloch v. Maryland, 17 U.S. (4 Wheat.) 316, 403 (1819) (describing "the people . . . assembled" in "convention" in the "several states" to ratify constitution). 
V, so too do first principles and various other parts of the federal Constitution require us to abandon the seeming exclusivity of Article V itself. ${ }^{150}$

But this result no doubt unsettles and disorients. If correct, we need to seriously rethimk much of constitutional law. But can it really be correct? Have we taken a wrong turn somewhere? Let's go back and consider a few possible objections.

\section{A. The Novelty Objection}

"Amar's First Theorem cannot be right. It is a huge claim, going to the very essence of our constitutional order. If correct-or even plausible-surely someone would have offered it before, or even tried to act upon it. It is just too novel to be true."

Novel to whom? Surely not to We the People of 1787 who did ordain and establish our Constitution-for as I hope I have shown, they understood and self-consciously acted upon the First Theorem and its underlying principle of majority rule popular sovereignty. To repeat the words of that pre-eminent legal theorist James Wilson: "The consequence is, that the people may change the constitutions whenever and however they please. This is a right of which no positive institution can ever deprive them." 151 "A majority of the society is sufficient for this purpose."152

But the "First Theorem" will no doubt seem novel to many of us today-even (or perhaps especially) lawyers, judges, and scholars. But is it possible that the novelty is rooted in our own ignorance?

For example, we have not been taught-in high school civics, in college classrooms, in Supreme Court opinions, or even in law school casebooks and law reviews, just how central James Wilson was to the Founding generation, and to the Founding itself. Serious students of the Constitution pore over every nuance of The Federalist Papers, but how many of us have spent even a fraction of time studying James Wilson's equally influential, broad and deep speeches and lectures from 1787 to 1791 ?

And could it be that our entire perspective on the place of majority rule in our Constitution is askew? Preoccupied with the "countermajoritarian difficulty" posed by judicial review, the last generation of constitutional scholars spun ever more elaborate theories about the most "filtered" parts of the Constitution-such as Article III-yet all but ignored its most directly majoritarian clauses, such as the Preamble and Article VII. Rather than dwelling only on whether and how unelected judges can create or evolve new individual rights, we need to see how the

150. Ultimately, my claim is not narrowly intentionalist, but structural. Even if many Framers failed to appreciate all the implications of their constitution, the logic of that constitution, in both word and deed, supports my claim. And the most clear-eyed and important constitutional architect of popular sovereignty, James Wilson, clearly did understand-and sought to expound-that logic.

151. See supra note 58 and accompanying text.

152. See supra note 110 and accompanying text. 
People ordained the supreme law by majority rule popular sovereignty and to ask, could the People do this again?

Indeed, we have spent far too little attention generally pondering the processes of constitutional change. ${ }^{153}$ Article III, various individual rights, and much of the rest of the Constitution could in theory be amended away. Analytically, much of our existing constitutional order exists in the shadow of constitutional amendment rules, yet these rules have received far less serious theoretical attention than their special status demands. And to understand how the Constitution can be legally amended, we must better understand how it was legally brought into existence. The majoritarian Preamble and Article VII-literally the original Constitution's textual and performative alpha and omega-stand on an analytically higher plane than "countermajoritarian" provisions like those in Article III. ${ }^{154}$

When sophisticated theorists do touch on the Preamble, or Article VII, it is too often with a cynical smirk on their lips: who but a rube could take seriously the winkingly democratic phrase, "We the People"? ButCharles Beard notwithstanding ${ }^{155}$ - the act of the constitution was not some antidemocratic, Thermidorian counterrevolution, akin to a coup d'etat, but was instead the most participatory and majoritarian event the planet had ever seen (and lawful to boot). Looking backwards from today, we see all the painful exclusions-of women, of slaves-but often miss the breadth of inclusion, looking backwards from 1787.156

153. For a recent attempted corrective, see generally Michael S. Paulsen, A General Theory of Article V: The Constitutional Lessons of the Twenty-Seventh Amendment, 103 Yale L.J. 677 (1993).

154. And also than Article $\mathrm{V}$ itself, which is best read as a revocable delegation of special lawmaking power to ordinary government, akin to, but more powerful than, Article I delegation, yet ultimately subordinate to the people themselves. Indeed, though not definitively answering all Article $\mathrm{V}$ conundra, the framework and evidence presented in this essay throw hight on some of the important Article $V$ issues identified earlier, see supra notes 9-10 and accompanying text. An Article $V$ proposing convention should follow majority rnle (it goes without saying) and be apportioned by national population. An amendment outside Article V could modify Article V rules, but could not eliminate the non-Article $V$ right of a majority to make future amendments, since that right is inalienable, and constitutive of the Constitution's popular sovereignty essence. The very logic of popular sovereignty both empowers amendments in general, yet prevents "unamendable" Amendments. This logic itself, of course, from one perspective constitutes a kind of unamendability. This is the paradox of sovereignty-akin to the theological paradox concerning God's sovereign ability to bind God's self (if God is omnipotent, can She create a rock so heavy She cannot lift it?) - but a paradox at the heart of self-rule. Cf. Charles L. Black Jr., The People and the Court 223-25 (1960). Even if the people of one generation could bind itself to an "unamendable" or extraordinarily-difficult-to-amend substantive provision, by what right could the people of one generation so bind the next?

155. See generally Charles A. Beard, An Economic Interpretation of the Constitution of the United States (1913).

156. Again, suffrage rules for constitutional ratification were broader than those applicable for ordinary legislative elections. See supra note 8 and accompanying text; supra text accompanying note 86 . 
Americans did not receive their supreme law from On High, from some Great Man claiming a pipeline to God-Moses, Solon, Lycurgus-or from some conclave of fifty-five demigods in Philadelphia (which merely proposed a piece of paper). ${ }^{157}$ Nor did Americans simply inherit their supreme law from immemorial custom. Rather, Americans did ordain and establish their supreme law-peacefully, deliberately, and lawfullyby majority rule popular sovereignty. The act electrified Europe and doomed the ancien regime.

The novelty objection, in short, suffers from remarkable amnesia concerning the Constitution's words and deeds. Conventional wisdom about the federal Bill of Rights is not much better. Mainstream scholars and citizens stress the Bill's commitment to individual and minority rights, but miss its even larger majoritarian and populist themes ${ }^{158}$ themes also evident in the state declarations quoted and discussed above. How could the mainstream forget, for example, that no phrase appears in more of the first ten amendments than "the people"?

The obvious overlaps between state declarations of rights and the federal Bill should remind us of the general importance of the state constitutional experience in shaping American constitutional discourse. Yet here, too, the mainstream suffers from amnesia. To my knowledge, no modern legal scholar has carefully examined the state Article $\mathrm{V}$ analogues from 1787 and pondered their significance for Article V itself. And perhaps because of the pervasive nationalism of today's law schools, few constitutional scholars are even aware of the dramatic pattern of majority rule popular sovereignty in amending state constitutions after 1787.

In 1790, for example, James Wilson and his allies succeeded in convening a special convention to replace the Pennsylvania constitution of

157. The Federalists repeatedly emphasized that the Philadelphia Convention's proposal was merely a piece of "paper" until ratified and made law by the people, assembled in special ratifying conventions. See, e.g., The Federalist No. 40, at 252 (James Madison) (Clinton Rossiter ed., 1961); 2 Elliot's Debates, supra note 18, at 470 (remarks of James Wilson in Pennsylvania ratifying Convention) (equating proposed Constitution with a "production ... f flowing from a private pen"); 4 id. at 23 (remarks of William R. Davie at North Carolina ratifying convention) (similar); id. at 24 (remarks of William Maclaine at North Carolina ratifying convention) ("The Constitution is only a mere proposal."); id. at 206 (remarks of Richard D. Spaight at North Carolina ratifying convention) (similar); 3 id. at 38 (remarks of Edmund Pendleton at Virginia ratifying convention) (similar). For further documentation and discussion, see Elaine Scarry, War and the Social Contract: Nuclear Policy, Distribution, and the Right to Bear Arms, 139 U. Pa. L. Rev. 1257, 1271 \& n.39, 1313-14 (1991). Even though proposing a new Constitution did go beyond the Philadelphia delegates' commissions, as Madison explicitly admitted in The Federalist No. 40, he nowhere conceded that the mere proposal was somehow "illegal," as Professor Ackerman erroneously claims. See Ackerman, supra note 13, at 328 n.4. For those who believe in free expression, the worst one could say about the proposal was that it was "void"-a legal "nullity" perhaps, but hardly "illegal." (Ackerman's implicit theory of "illegality" here is a scary one indeed.) And Madison's argument is that the proposal is indeed of zero legal significance-unless and until ratified by the People and thereby made supreme law.

158. See generally Amar, The Bill of Rights as a Constitution, supra note 142. 
1776, despite arguments that the council of censors clause was exclusive. ${ }^{159}$ Whence this second, majority rule popular sovereignty mode, outside Pennsylvania's Article V analogue? "A Freeman" in the Federal Gazette furnished the answer- "[T]he [state] Constitution itself admits and maintains the never ceasing power of the People to change their frame of government" - and proceeded to quote the Declaration of Independence and the Pennsylvania Constitution of $1776 .{ }^{160}$ To similar effect were the Gazette's editors:

[W] hen the people prescribed in the constitution a council of censors, as the ordinary mode of altering that civil compact, they reserved in express terms the right of altering it at any time and any manner they should see fit. From hence it is clear, that however constitutional a council of censors will hereafter be, a convention of the people were equally constitutional, in December, 1788 [to ratify the federal Constitution], and will be so in the present year-This power of electing a convention at all times, to alter the constitution of a state, is a never dormant-never ceasing uncontrollable right of the people. ${ }^{161}$

The following year, Delaware followed suit, holding a constitutional convention in the teeth of its own seemingly exclusive Article V analogue; and this was only the beginning. As Massachusetts Assistant Attorney General Roger Sherman Hoar-whose Founding era namesake we have already encountered-documented in a 1917 book, innumerable amendments to state constitutions occurred in countless states in the nineteenth century by modes of popular majority action not explicitly authorized by pre-existing state constitutions, and often in the teeth of what at first seemed exclusive Article V analogues. ${ }^{162}$ Here is what one of Hoar's earliest predecessors, William Rawle, wrote in his famous treatise on the federal Constitution in the 1820s:

[T] he people retains-the people cannot perhaps divest itself, of the power to make [constitutional] alterations. A moral power equal to and of the same nature with that which made, alone can destroy. ... So the people may, on the same principle, at any time alter or abolish the constitution they have formed. This has been frequently and peaceably done by several of these states since 1776. If a particular mode of effecting such alterations is agreed on, it is most convenient to adhere to it, but it is not exclusively

159. The material in this paragraph derives from Matthew Herrington's important manuscript, supra note 60 , at 53-54.

160. Id. at 54 (quoting A Freeman, Federal Gazette, Mar. 28, 1789).

161. Id. at 54 n.114 (quoting Federal Gazette, Mar. 28, 1789) (emphasis added). See also id. at 56.

162. See Hoar, supra note 105, at 39-40 (listing 34 conventions held before 1917 in 18 states whose constitutions did not explicitly authorize them). This book is a must read for those who continue to have doubts about the nonexclusivity of state Article $V$ analogues. 
binding. We shall hereafter see the careful provision in this respect contained in the constitution of the United States. ${ }^{163}$

In short, both in word and in deed, majority rule popular sovereignty was alive and well throughout the nineteenth century, if we only know where to look. ${ }^{164}$

To take one final example, the theory of Jefferson Davis and his fellow secessionists in 1861 was simple and clear: (1) Article V is not the exclusive mode of legitimate constitutional change; (2) We the People retain the right to alter or abolish our government at any time, and for any reason; (3) We the People exercise this right by simple majority rule in special convention; and (4) the relevant people is the people of each state. This was a theory that hundreds of thousands fought and died for. And, as I understand him, President Lincoln crossed swords with "President" Davis only over proposition Number 4, insisting-quite rightly, in my view-that secession could take place only if approved by a national majority, and not a mere statewide one.

\section{B. The Legal Objection}

"Perhaps the people do have a right to alter or abolish their government outside Article $\mathrm{V}$, but this right is not a legal right, a constitutional right. It is something else-supra-constitutional, extralegal, natural, philosophical, or revolutionary, perhaps, but definitely not legal and constitutional in the way that Article V is."

Why not? Surely the Constitution could have said, in so many words: "Article V is not exclusive. The People retain the legal right to change the Constitution by legal mechanisms akin to the legal mechanisms by which they ordained and established it." My claim is that the Constitution is best read as saying exactly this, only in different words-the Preamble, the Ninth and Tenth Amendments, and so on-and in the act of legal ordainment and establishment itself.

163. William Rawle, A View of the Constitution of the United States of America 12 (Philadelphia, H.C. Carey \& I. Lea 1825) (emphasis added) (footnote omitted).

164. These vigorous assertions of majority rule popular sovereignty should put to rest the notion that the right of the people to alter and abolish somehow lapsed through desuetude or nonuse after 1789 .

The desuetude argument is troubling on other grounds as well. Does the nonuser of two of Article V's four paths mean that they too have somehow lapsed? (As we have seen, majority rule popular sovereignty is no less a part of our Constitution than, say, Article V.) Does the fact that the People have not felt the need to invoke a particular right mean that they have explicitly waived it? Forever? Even if We the People could waive our own right to alter or abolish, how could we waive our grandchildren's-especially given that the very logic of the right insists that it be inalienable?

The waiver argument does, however, highlight one important feature of majority rule popular sovereignty: this right would have bite only in a world where a majority of the polity was indeed persuaded that the right was in our Constitution, akin to the unused tracks of Article V. 
When Jefferson penned his Declaration of Independence, simple majority rule popular sovereignty had not yet achieved full legal protection in America, so the colonists perforce had to rely only on a "natural" or "revolutionary" right of resistance. But in the ensuing years, they legalized and codified majority rule popular sovereignty, and gave it institutional form with the perfecting of the convention device. The state declarations did not describe this right as merely "revolutionary" or "natural"; rather they cloaked it with full legal protection, just as they accorded, say, "speech" and "conscience" legal protection in many cases.

Popular sovereignty majority rule is every bit as much a part of our Constitution, in word and deed, as Article V. Yet the legal objection does capture one key difference: the popular sovereignty amendment path is legally higher than Article V. Article V is not inalienable; popular sovereignty is. Article $\mathrm{V}$ could be amended away, but popular sovereignty cannot. Article $V$ only supplements, but can never supplant, majority rule popular sovereignty.

Of course, in implementing either Amendment path, faithful constitutional interpreters will confront a host of difficult questions. How would a proposing convention under Article $V$ operate? How should a ratifying convention or referendum outside Article V best be structured?

I leave these implementation issues for another day. For now, it suffices to say that these issues arise both within Article V and outside it; that in both cases, ordinary government officials must participate in good faith in implementing the Amendment process, even if they oppose an Amendment's substance; and that past implementation practice, especially at the state level, provides a rich collection of precedents on many otherwise difficult questions.

But before we can even begin to ask these questions about implementing the non-Article $V$ path, we must accept its existence-within our Constitution, parallel to Article V, never lower than it, and if anything even higher than it.

\section{The New Constitution Objection}

"Even if We the People do have a right to re-Constitute our regime by majority rule popular sovereignty outside Article V, this right is not a right to amend our existing Constitution but a right to promulgate an entirely new and different Constitution. Popular sovereignty outside Article V thus means the death of our Constitution, not an amendment of it."

The distinction here is largely nominal. An "amendment," after all, can often radically re-write the text being amended. Consider, for example, an "amendment" to a pending bill that is in fact a substitute bill, from start to finish-or a purported 28th Amendment to the U.S. Constitution that begins: "Sec. 1. The foregoing is hereby repealed. Sec. 2. We the People . ..." Alternatively, a "new Constitution" could read word for word like the old in every way but with a few new items. 
The real distinction-or at least the one I am focusing on here-is between a new substantive rule (whether labelled an "amendment" or a "new Constitution") that becomes supreme law by a legal process provided for by our existing Constitution, and one that does not-that bootstraps itself into existence by its own self-defined rule of recognition. And my claim is that popular sovereignty majority rule falls on the same side of this line as Article $V$ amendment; both are provided for by our existing Constitution, and neither is akin to a coup d'etat. (A coup can be peaceful and even popular, but its "legality" is only an ex post artifact of its success and not an emblem of its ex ante conformity with the rules for lawful change laid down under the prior regime.)

The distinction between procedures for constitutional change authorized by our existing Constitution (Article $\mathrm{V}$ and majority rule popular sovereignty) and procedures prohibited by it (a "coup," however peaceful and popular) is vital. Citizens, lawmakers, and judges who have taken oaths to support our Constitution may-and in some cases must-cooperate in implementing the legal procedures under Article $V$ and majority rule popular sovereignty. Even if oath-takers ratify a "new Constitution," they are not in the process violating or betraying the old one, but acting in pursuance of its deepest norms, practicing what it preaches, flattering and honoring its framers by legally imitating them.

\section{The Deliberation Objection}

"Does the First Theorem mean that the majority can do anything it wants? Instantaneously? Surely majority rule must at least be deliberate rather than whimsical. And so multiple vote and minority veto rules should be permitted, so long as they truly do induce deliberation."

It does not necessarily follow from the First Theorem that the majority can simply do whatever it likes. Majority rule does not necessarily imply majority will or majority whim. James Wilson, for example, clearly stated that the People stood under God and natural law; and that a majority was not entitled to do simply whatever it pleased:

[A]s the law of nature, in other words, as the will of nature's God, it is indispensably binding upon the people, in whom the sovereign power resides; and who are, consequently, under the most sacred obligations to exercise that power, or to delegate it to such as will exercise it, in a manner agreeable to those rules and maxims, which the law of nature prescribes to every state, for the happiness of each, and for the happiness of all. How vast-how important-how interesting are these truths! They announce to a free people how exalted their rights; but, at the same time, they announce to a free people how solemn their duties are. If a practical knowlege [sic] and a just sense of these rights and these duties were diffused among the citizens, and 
properly impressed upon their hearts and minds; how great, how beneficial, how lasting would be their fruits! ${ }^{165}$

There is no paradox or contradiction here. Wilson is simply reminding us that, just as Parliament as sovereign was both supreme legislature and supreme judiciary in England, so in America were the people. As judges they were indeed bound by the higher law of God; but legally, they were the earthly judges of that law, the True and Ultimate Supreme Court. Sitting in their judicial capacity, they had duties as well as rights, and could not simply do whatever they pleased if doing so would indeed trench on inviolable rights. And in exercising their judicial judgment, as in exercising their legislative will, the People act by simple majorities-as do inferior legislatures and courts, as a general rule. (The Supreme Court under Article III acts by majority rule among the Justices; but that does not mean that, in theory, the Justices may simply do whatever they please.)

Wilson's model makes even more sense when we remember that constitutional amendments were not always understood as creating new rules by legislative fiat. On the contrary, we have seen that amendments were often understood as judicial declarations of existing rights that individuals and entities had under custom or natural reason or both.

In order to deliberate properly-legislatively as well as judiciallythe People must indeed be exposed to and must engage opposing ideas; the majority should attempt to reason with and persuade dissenters, and vice versa. Majority rule popular sovereignty presupposes a deliberate majority of the collective "people," not a mere mathematical concatenation of atomized "persons." In the words of Publius' opening sentence: " $[Y]$ ou are called upon to deliberate on a new Constitution for the United States of America."166

Because the requisite convocations and deliberations could not occur en masse in 1787 among all voters, the Founders relied on smaller conventions to speak as and for the People. Direct special election for a single purpose would minimize the "agency gap" between convention and electors, but the convention could carry on extended deliberations and discussions that would be difficult in the polity at large. In 1787, a referendum would have been a less true index of the will and judgment of a deliberate majority, given that many voters in the referendum would not have had the benefit of focused discussion from the most articulate proponents of varying views.

Today, because of vast improvements in communication and transportation technology-radio, television, cable, fiber-optics, electronic town meetings, etc. - there may be ways to retain the deliberation of the convention while providing for even more direct popular participation,

165. 1 The Works of James Wilson, supra note 9 , at 153 .

166. The Federalist No. 1, at 33 (Alexander Hamilton) (Clinton Rossiter ed., 1961) (emphasis added). 
akin to referenda. (Perhaps, for example, citizens could assemble in caucuses in their towns and neighborhoods, and these assemblies could be electronically and interactively linked to focused debate in a central convention assembly. After hearing these debates themselves and having the opportunity to speak up in their local caucus, the citizens could then vote directly on the proposed amendment, rather than in effect surrendering their proxies to convention members.)

There thus remains considerable room for flexibility in implementing the deliberation requirement, including, perhaps, a requirement for two separate votes, spaced far enough apart to allow true conversation and conversion to occur, and for second thoughts to cool fleeting fancy. But there can be no similar compromise on the principle of simple majority rule. As the framing generation well understood, and modern political science has reaffirmed, simple majority rule has unique mathematical properties. It is the only workable voting rule that treats all voters and all policy proposals equally. ${ }^{167}$ Once majority rule is abandoned, there is no logical stopping point between, say, a $50 \%$ plus two rule, and a $99.9 \%$ rule. And the latter, of course, surely is not rule by the people.

Thus, in the pregnant phrase "deliberate majority," there is no unique mechanism for ensuring deliberation, but majority rule does have a unique instantiation. The people must talk, listen, and vote, and that takes time. (By its very nature, the people's right to alter or abolish "at any time" cannot be instantaneous.) But when they do vote, a majority, however small, must in the end prevail over a minority.

\section{E. The Individual Rights Objection}

"But what about individual rights?"

In the end, individual rights in our system are, and should be, the products of ultimately majoritarian processes. Once again, there is nothing paradoxical about this. Sloppy philosophical rhetoric notwithstanding, there is nothing in the ontological character of a "right" that requires that it be vested in an "individual" or "minority" against the "majority." It is perfectly intelligible to speak of majority rights. And historically, many of the most important rights in the federal Bill of Rights and its state counterparts have been majoritarian rights of the people. ${ }^{168}$ Through majoritarian processes, We the People have also recognized rights of indi-

167. See Kenneth O. May, A Set of Independent Necessary and Sufficient Conditions for Simple Majority Decision, 20 Econometrica 680, 683 (1952) (simple majority rule is only mechanism that does not (1) favor one individual over another, (2) favor one alternative over another, (3) fail to generate a definite result in some situation, or (4) fail to respond positively to individual preferences). For discussion of a voting mechanism that in some situations can satisfy the first three conditions, see Bruce A. Ackerman, Social Justice in the Liberal State 284-89 (1980) (discussing "responsive lotteries"); Akhil Reed Amar, Note, Choosing Representatives by Lottery Voting, 93 Yale L.J. 1283, 1292-1308 (1984) (discussing "lottery voting" for candidates).

168. See generally Amar, The Bill of Rights as a Constitution, supra note 142. 
viduals and minorities, and extended the right to be part of We the Polity to formerly excluded elements of society like black men and women of all races. ${ }^{169}$

Conventional wisdom emphasizing "countermajoritarian" judicial review to protect unpopular rights is also shortsighted. Presidents select judges, and Presidents are elected by majorities. In the long run, rights will only be safe if they are understood and accepted by the polity, and not just the judges.

Because each citizen sees herself as in the minority on some issues, each is likely to embrace some general idea of "minority rights" out of long term self-interest, as well as fairness. Indeed, if any citizen feels that the Constitution should not be lightly amended-at any time, for any reason, by simple majority rule-she is free to vote against any substantive amendment she might otherwise favor on second order procedural/prudential grounds based on the breadth, depth, or distribution of substantive opposition to the amendment. Popular sovereignty does not prevent us from striking a balance in our own minds that strongly privileges the constitutional status quo. But popular sovereignty does prevent us from denying future generations of popular majorities-our posterity-the right to strike a different balance.

The individual rights objection may also prove too much, for at least some variants are opposed to any amendment of certain rights. But the question before the house is not whether amendment can occur, but how. Why do individual rightists trust Government with the power to amend but not the People? To be sure, Government must act with supermajorities-but that is precisely because Government officials often have interests separate from their constituents, in ways that often threaten liberty. The malapportionment at the heart of Article $\mathrm{V}$ ratification-counting Utah and California equally-creates further grounds for skepticism and suspicion. It is easy to imagine conditions under which an amendment might clear Article V's hurdles even if opposed by a majority of the American electorate.

A further turn of the screw: Article V, if exclusive, seems to say anything goes; no right is immune from abandonment-except Senate equality and (prior to 1808) the slave trade. So much follows from the logic of expressio unius and a blindered examination of Article $\mathrm{V}$ in isolation. But these are the very flawed interpretive premises the "First Theorem" challenges. Once we see the Constitution through, say, James Wilson's eyes, we see that perhaps not everything is properly amendable. Certain higher law principles-including popular sovereignty majority rule, but encompassing other inalienable rights as well-frame Article V itself. If we look at state declarations, we see, for example, that the individual "right of conscience" may, like popular sovereignty itself, be "unalienable." Ordinary Government should arguably not be allowed to 
amend this away-despite the fact that Article $V$ itself says nothing explicit about "conscience"-at least in the absence of a solemn (judicial) declaration of the People themselves, in convention assembled, that they no longer judge conscience an "inalienable" right. ${ }^{170}$

Or to pick a much easier example: the very logic of popular sovereignty itself implies that there is an unalienable "Meiklejohn core"171 of the First Amendment-that minimal amount of free expression constitutive of republican self-government itself, and logically implied by the people's right to alter or abolish. (How can the people exercise this right against Government if they cannot speak against Government?) Ordinary Government should not be allowed to amend away this Meiklejohn core, even if ordinary Government strictly follows the rules of Article V. Such an amendment should be treated by judges as unconstitutional-a kind of coup d'etat, violative of first principles of our constitutional order, despite formal compliance with Article V.

But this kind of thinking-which should warm the hearts of some individual rightists-is intelligible only if we reject the flawed interpretive premises that lead to Article V exclusivity.

\section{F. The Geographic Objection}

"But doesn't Article V exist to protect geographic minorities?"

No. Analytically, the rules of Article V may be satisfied even if an amendment is fiercely opposed in one geographic section of the country. And the analytic point has powerful empirical support. The leading political science study of the federal amendments since the Founding, authored by Alan Grimes, concludes that a dominant "characteristic of amendment politics has been the sectional or regional aspect of the political struggle."172 The very titles of Grimes's chapters are devastating to the geographic objection. Amendments One through Twelve are labelled "The Southern Amendments," Thirteen through Fifteen "The Northern Amendments," Sixteen through Nineteen "The Western Amendments" and Twenty-three through Twenty-six "The Urban Amendments." 173

Indeed, the framers explicitly rejected the premise underlying the geographic objection. In response to concerns at Philadelphia that one day, the population of Western states would overwhelm the East, James Wilson proclaimed:

170. The argument in this paragraph tracks Jeff Rosen's fascinating Note, Was the Flag Burning Amendment Unconstitutional?, 100 Yale L.J. 1073 (1991). Though I am not sure I ultimately agree with Rosen's argument, it is plausible and important.

171. I invoke here the brilliant work of Alexander Meiklejohn. See generally Alexander Meiklejohn, Political Freedom: The Constitutional Powers of the People (1960); Alexander Meiklejohn, The First Amendment Is an Absolute, 1961 Sup. Ct. Rev. 245.

172. Alan P. Grimes, Democracy and the Amendments to the Constitution 26 (1978).

173. Id. at vii. 
Conceiving that all men wherever placed have equal rights and are equally entitled to confidence, [I view] without apprehension the period when a few States should contain the superior number of people. The majority of people wherever found ought in all questions to govern the minority. If the interior Country should acquire this majority they will not only have the right, but will avail themselves of it whether we will or no. ${ }^{174}$

That a majority within a polity should rule, regardless of geographic distribution, is confirmed not just by the leading Founder's words buthere too-by the act of constitution itself. Georgia's Article V analogue ${ }^{175}$ required a majority within each Georgia county and yet the analogue, like those of its sister states, was supplemented by Article VII's simple majority vote of the state convention as a whole regardless of geography.

\section{G. The Federalism Objection}

"But are states within the union truly akin to counties within states? Perhaps the First Theorem is indeed true as a matter of state constitutional law; but doesn't the federal-or at least, mixed-nature of our continental union render state Article $V$ analogues ultimately not analogous?"

Here, at last, we come to the hardest objection to my "First Theorem." We have reached a fork in the road, and must choose one of three paths. And that choice will make all the difference.

Path \#1 was Jefferson Davis's: The people of each state remained sovereign even after union, and as such, retained the inalienable rightnotwithstanding Article V-to alter or abolish their Government, and even withdraw from the Union, by simple majority rule popular sovereiguty state by state.

Path \#2 was James Wilson's: After ratification under Article VII, We the People became-if we were not already before- a truly continental people. So far as the continental Constitution was concerued, majority rule popular sovereiguty outside Article $\mathrm{V}$ meant a national majority. State peoples continued to exist, and in effect enjoy sovereign powers over their own state legislatures and state constitutions. And thus, for state constitutional purposes state peoples continue to retain the right to alter or abolish outside their state Article $\mathrm{V}$ analogue. But the state people is clearly subordinate to the national people, just as state constitutions are subordinate to the national Constitution. The people of a single state may not nullify the federal Government's action, but the national people may. Unilateral secession by the part is void, but the whole people can peacefully agree to divide, just as they can agree to merge with other peoples-for example, by admitting Texas. 
Path \#3 was James Madison's: Ordinary government under the Constitution was neither wholly "national," nor purely "federal"-_federal" here meaning league-like, as in the "Articles of Confederation." As with ordinary government, so too with constitutional amendment. Neither the people of each state nor the people of the nation were wholly sovereign. Sovereignty had somehow been divided, with Article $V$ embodying the precise-exclusive-terms of the division.

Which path is most plausible? Not, I think, Jefferson Davis's. For the text of the Constitution makes clear in Article VI that any state constitutional provision-even if adopted by majority rule popular sovereignty in a state-is inferior to the federal Constitution. And Article V makes clear that a state people can be bound by a federal amendment even if that state people in state convention explicitly rejects the amendment. (Here, Article V differs dramatically from Article VII.) Both of these provisions are logically inconsistent with the sovereignty of the people of each state. And if we examine the constitution of 1787 as an act, and not a mere text, we will find no one-on either side of ratification-asserting that after ratification a state people could unilaterally secede at will. ${ }^{176}$

That leaves us with a choice between the Constitution's two greatest architects, James Madison and James Wilson. And on the vital question of popular sovereignty, Wilson-though less celebrated and studied todaywas the truer prophet, seeing further and more clearly.

Wilson built his argument axiomatically on the idea that sovereignty was absolute and indivisible. ${ }^{177}$ This view was almost universally held in the 1780s. Divided sovereignty was seen as a logical contradiction, a "solecism." 178 Indeed, so far as I can tell, Madison was the only major figure who believed in it.

Why did virtually no one follow Madison's lead on this point? Perhaps because they understood-as did Wilson and Davis, for examplethat "divided" or "mixed" popular sovereignty was no popular sovereignty. A fundamental principle for republican government was that the majority should rule, ${ }^{179}$ and divided sovereignty betrayed that fundamental principle. The formal principle of popular sovereignty, in other words, cannot tell us whether we should be a state people, or a national people, but it does insist that we be one or the other. (And since Davis was wrong, Wilson must be right.) For if sovereignty can indeed be divided-as only Madison believed-then We the People today cannot control our fate.

176. For more documentation and elaboration of these claims, see Amar, supra note 37, at 1451-66. And for discussion of the geostrategic logic undergirding all this see Akhil Reed Amar, Some New World Lessons for the Old World, 58 U. Chi. L. Rev. 483, 485-91 (1991).

177. See supra text accompanying note 58 .

178. See Wood, supra note 6, at 345; Amar, supra note 3, at 1063 \& n.71.

179. See supra text accompanying notes 85-113. 
A concluding example should make this clear. Women today constitute a majority of both the Massachusetts and American polities. They are today governed under a federal Constitution largely the making of men who died long ago, men who may not have had their interests foremost in mind. If either the Massachusetts or American People is sovereign, women-in combination with like-minded men-could by simple majority vote alter or abolish patriarchal rules in the federal Constitution, following Davis or Wilson. But if sovereignty can indeed be divided, and Article V enshrined as exclusive, the women of Massachusetts-and of each of the other states-have lost their right of majority rule self-government. They must rely on ordinary Government officials-overwhelmingly men - to act by supermajorities in order to, say, enshrine the Equal Rights Amendment. ${ }^{180}$

This is not popular self rule; it is rule from cold graves of dead men of constitutions past, and by small clumps of old men in ordinary Government. For me at least, one of the best reasons for embracing the "First Theorem" is the self-evident truth that women, too, are created equal.

180. Nor is the fact that women can "vote the rascals out" a sufficient answer. As we have seen, supra note 8 , the structure of elections for individual legislators places the electorate in each district in a prisoners' dilemma, where a vote against the incumbent will cause the district as a whole to lose predicted benefits vis-á-vis other districts. This example illustrates once again how a one-shot convention differs in important structural ways from an on-going legislature, with the electorate having much less control over the latter. 